\title{
Agricultural peatlands: towards a greenhouse gas sink - a synthesis of a Dutch landscape study
}

\author{
A. P. Schrier-Uijl ${ }^{1}$, P. S. Kroon ${ }^{2}$, D. M. D. Hendriks ${ }^{3}$, A. Hensen ${ }^{2}$, J. Van Huissteden ${ }^{4}$, F. Berendse ${ }^{1}$, and \\ E. M. Veenendaal ${ }^{1}$ \\ ${ }^{1}$ Nature Conservation and Plant Ecology, Wageningen University, Droevendaalse steeg 3a, 6708 PD Wageningen, \\ the Netherlands \\ ${ }^{2}$ Energy Research Centre of the Netherlands (ECN), Department of Air Quality and Climate Change, 1755 LE Petten, \\ the Netherlands \\ ${ }^{3}$ Deltares, Department of Soil and Groundwater Systems, Princetonlaan 6, 3584 CB Utrecht, the Netherlands \\ ${ }^{4}$ Hydrology and Geo-Environmental Sciences, Faculty of Earth and Life Sciences, Vrije Universiteit Amsterdam, \\ De Boelelaan 1085, 1081 HV Amsterdam, the Netherlands
}

Correspondence to: A. P. Schrier-Uijl (arina.schrier@planet.nl)

Received: 2 May 2013 - Published in Biogeosciences Discuss.: 17 June 2013

Revised: 25 June 2014 - Accepted: 3 July 2014 - Published: 28 August 2014

\begin{abstract}
It is generally known that managed, drained peatlands act as carbon (C) sources. In this study we examined how mitigation through the reduction of the intensity of land management and through rewetting may affect the greenhouse gas (GHG) emission and the $\mathrm{C}$ balance of intensively managed, drained, agricultural peatlands. Carbon and GHG balances were determined for three peatlands in the western part of the Netherlands from 2005 to 2008 by considering spatial and temporal variability of emissions $\left(\mathrm{CO}_{2}, \mathrm{CH}_{4}\right.$ and $\mathrm{N}_{2} \mathrm{O}$ ). One area (Oukoop) is an intensively managed grasson-peatland area, including a dairy farm, with the ground water level at an average annual depth of $0.55( \pm 0.37) \mathrm{m}$ below the soil surface. The second area (Stein) is an extensively managed grass-on-peatland area, formerly intensively managed, with a dynamic ground water level at an average annual depth of $0.45( \pm 0.35) \mathrm{m}$ below the soil surface. The third area is a (since 1998) rewetted former agricultural peatland (Horstermeer), close to Oukoop and Stein, with the average annual ground water level at a depth of $0.2( \pm 0.20) \mathrm{m}$ below the soil surface. During the measurement campaigns we found that both agriculturally managed sites acted as $\mathrm{C}$ and GHG sources and the rewetted former agricultural peatland acted as a $\mathrm{C}$ and GHG sink. The ecosystem (fields and ditches) total GHG balance, including $\mathrm{CO}_{2}, \mathrm{CH}_{4}$ and $\mathrm{N}_{2} \mathrm{O}$, amounted to $3.9( \pm 0.4), 1.3( \pm 0.5)$ and $-1.7( \pm 1.8) \mathrm{g} \mathrm{CO}_{2}$-eq $\mathrm{m}^{-2} \mathrm{~d}^{-1}$ for Oukoop, Stein and
\end{abstract}

Horstermeer, respectively. Adding the farm-based emissions to Oukoop and Stein resulted in a total GHG emission of $8.3( \pm 1.0)$ and $6.6( \pm 1.3) \mathrm{g} \mathrm{CO}_{2}$-eq $\mathrm{m}^{-2} \mathrm{~d}^{-1}$, respectively. For Horstermeer the GHG balance remained the same since no farm-based emissions exist. Considering the $\mathrm{C}$ balance (uncertainty range 40-60\%), the total $\mathrm{C}$ release in Oukoop and Stein is 5270 and $6258 \mathrm{~kg} \mathrm{Cha}^{-1} \mathrm{yr}^{-1}$, respectively (including ecosystem and management fluxes), and the total $\mathrm{C}$ uptake in Horstermeer is $3538 \mathrm{~kg} \mathrm{Cha}^{-1} \mathrm{yr}^{-1}$. Water bodies contributed significantly to the terrestrial GHG balance because of a high release of $\mathrm{CH}_{4}$.

Overall, this study suggests that managed peatlands are large sources of GHGs and C, but, if appropriate measures are taken, they can be turned back into GHG and $\mathrm{C}$ sinks within 15 years of abandonment and rewetting. The shift from an intensively managed grass-on-peat area (Oukoop) to an extensively managed one (Stein) reduced the GHG emissions mainly because $\mathrm{N}_{2} \mathrm{O}$ emission and farm-based $\mathrm{CH}_{4}$ emissions decreased.

\section{Introduction}

Although peatlands cover only $6 \%$ of the terrestrial surface of the Earth, they play a central role in the global carbon $(\mathrm{C})$ cycle (Gorham et al., 2012). In their natural state, peatlands 
capture $\mathrm{C}$ as carbon dioxide $\left(\mathrm{CO}_{2}\right)$ with a long-term average uptake rate of $25 \mathrm{~g} \mathrm{C} \mathrm{m}^{-2} \mathrm{yr}^{-1}$ (Borren et al., 2006). Natural peatlands emit methane $\left(\mathrm{CH}_{4}\right)$ as a result of anaerobic conditions that lead to methanogenesis. The total balance between $\mathrm{CO}_{2}$ uptake and $\mathrm{CH}_{4}$ release is in most cases negative (sequestration of $\mathrm{C}$ ) and is dependent on moisture conditions, temperature, vegetation composition, availability of degradable substrates and microbial activity (e.g. Hendriks et al., 2009). Generally, nitrous oxide $\left(\mathrm{N}_{2} \mathrm{O}\right)$ does not play a significant role in the greenhouse gas (GHG) budgets of natural peatlands. While natural peatlands act as sinks for $\mathrm{C}$, agricultural peatlands commonly act as sources for C and GHGs.

In Europe, $50 \%$ of all peatlands are subject to various sorts of agricultural practices (Joosten and Clarke, 2002), often associated with drainage resulting in oxidation of peat and release of $\mathrm{CO}_{2}$ to the atmosphere. In the Netherlands about 270000 ha (7\% of the land surface) is peatland, of which between 5 and $10 \%$ is defined as "water bodies". Since the industrial period, the Dutch peat soils have been heavily drained and fertilized and have turned into $C$ sources (e.g. Langeveld et al., 1997; Veenendaal et al., 2007). As a result of drainage and oxidation, peat subsidence rates in the Netherlands are up to $10 \mathrm{~mm} \mathrm{yr}^{-1}$ and already $20 \%$ of the original peat soils are now classified as mineral soil because the peat layer disappeared (Kempen et al., 2009). In wet peatlands, $\mathrm{CH}_{4}$ is commonly released (e.g. Carter et al., 2012; Teh et al., 2011; Schrier-Uijl et al., 2010; Hendriks et al., 2007). Water bodies in peat ecosystems are important contributors to the GHG balance because of high $\mathrm{CH}_{4}$ emissions and it is therefore important to consider them when calculating GHG budgets (Schrier-Uijl et al., 2011; Billet and Harvey, 2012). While $\mathrm{N}_{2} \mathrm{O}$ emissions do not play a significant role in the GHG budgets of natural peatlands, in intensively managed peatlands, high inputs of chemical fertilizer and manure lead to increased $\mathrm{N}_{2} \mathrm{O}$ emissions.

Three Dutch sites with similar characteristics have been studied and compared: an intensively managed site (Oukoop), an extensively managed site (Stein) and a rewetted/restored peatland (Horstermeer). Both the Horstermeer site and the Stein site are former intensively managed sites. Horstermeer was abandoned in 1998 and has become rewetted since, and only the water table is still regulated. Stein has gradually become an extensively managed site, and since 2001 the site has been managed as a bird reserve. Different land form elements (fields, ditches, saturated ditch edges) are part of the total landscape of the three sites. These land form elements need to be considered in assessing the spatial variability of fluxes within sites. By studying the GHG and C balances of these three sites, the effect of restoration and rewetting can be determined in the longer term and the results can also be used for a preliminary emission inventory at larger (peatland) scale: the spatial upscaling of emissions to the main land use categories on peat in the Netherlands.

The studies that published the first programme results are Schrier-Uijl et al. (2009, 2010, 2011), Kroon et al. (2010a, b, c), Hendriks et al. (2007) and Veenendaal et al. (2007). In this paper, results of later years have been analysed and combined with the initial data sets, and now we present the synthesis of this landscape scale experiment where 3-4 years of simultaneous measurements of $\mathrm{CO}_{2}, \mathrm{CH}_{4}$ and $\mathrm{N}_{2} \mathrm{O}$ have been performed with chamber and micrometeorological techniques on land and water. By having the system boundaries set at landscape level, (grass) biomass $\mathrm{C}$ import and export have also been considered for the $\mathrm{C}$ balance, as well as inputs of fertilizers and manure, export of milk and meat, and the loss of dissolved organic carbon (DOC) through drainage ditches. An overview of the GHG fluxes and C fluxes that have been considered in the calculation of balances for the three sites is given in Fig. 1.

Although peatland restoration and sustainable use is highly critical for the long-term viability of peatland ecosystems, there are still few comprehensive studies that report on the effects of peatland restoration activities on the total GHG emission and $\mathrm{C}$ balances. Our study is part of a programme that was designed to study the effects of peatland restoration, and we hope that this study will bring some more clarity on the effects of peatland rewetting in the Netherlands.

\section{Materials and methods}

\subsection{Site descriptions}

At three lowland peatlands in the mid-west of the Netherlands, the exchange of $\mathrm{CO}_{2}, \mathrm{CH}_{4}$ and $\mathrm{N}_{2} \mathrm{O}$ between the soilplant continuum and the atmosphere is measured in detail at scales from $1 \mathrm{~m}^{2}$ (chamber measurements) to $1000 \mathrm{~m}^{2}$ (eddy covariance techniques) in order to robustly investigate the effect of restoration on the GHG balance. Measurements at these different scales are cross-validated and the resulting data are used for determination of annual balances, determination of spatial and temporal variability and for upscaling of emissions.

The three research sites (Oukoop, Stein and Horstermeer) are located below sea level. The peat soil at the sites is a (Fibric) Eutric Histosol. The climate at the location of the three sites is temperate and humid, with a mean annual precipitation of about $800 \mathrm{~mm}$ and an annual mean temperature of $9.8^{\circ} \mathrm{C}$ measured over a 10 -year period before the measurement period (source: KNMI database). More detailed temperature and precipitation characteristics of Oukoop and Stein can be found in Veenendaal et al. (2007), and for Horstermeer in Hendriks et al. (2007). In Fig. 2 the average monthly water table and soil temperature is given for the three sites. Table 1 provides an overview of the main site characteristics and the management per site.

The Oukoop site $(\mathrm{Ou})$ is an intensively managed grassland polder on peat in the west of the Netherlands (lat. $52^{\circ} 02^{\prime} \mathrm{N}$, long. $4^{\circ} 47^{\prime} \mathrm{E}$; altitude $-1.8 \mathrm{~m}$ a.s.1.). The site is part of a dairy farm and grass is regularly mowed to feed cows that 
Table 1. Site descriptions, land use and management per peat site.

\begin{tabular}{|c|c|c|c|c|c|c|c|c|c|c|c|}
\hline Loc. & $\begin{array}{l}\text { Mean annual } \\
\text { WT depth } \\
\text { (SD) } \\
\text { (m) }\end{array}$ & $\begin{array}{l}\text { Peat } \\
\text { depth* } \\
\text { (m) }\end{array}$ & $\begin{array}{l}\text { Dry } \\
\text { land } \\
\%\end{array}$ & $\begin{array}{l}\text { Lanc } \\
\text { Wet } \\
\text { land } \\
\%\end{array}$ & $\begin{array}{c}\text { elements** } \\
\text { Saturated } \\
\text { land } \\
\%\end{array}$ & $\begin{array}{c}\text { Water } \\
\%\end{array}$ & Land use & Grazing $^{2}$ & $\begin{array}{l}\text { Biomass } \\
\text { removal }^{2} \\
(\mathrm{SD}) \\
\left(\text { ton } \mathrm{ha}^{-1} \mathrm{yr}^{-1}\right)\end{array}$ & $\begin{array}{l}\text { Cow manure } \\
\text { applied }^{2} \\
(\mathrm{SD}) \\
\left(\mathrm{kg} \mathrm{N} \mathrm{ha}^{-1} \mathrm{yr}^{-1}\right)\end{array}$ & $\begin{array}{l}\text { Fertilizer } \\
\text { applied }^{2} \\
(\mathrm{SD}) \\
\left(\mathrm{kg} \mathrm{N} \mathrm{ha}^{-1} \mathrm{yr}^{-1}\right)\end{array}$ \\
\hline $\mathrm{Ou}^{1}$ & $0.55( \pm 0.37)$ & 12 & 79 & & 5 & 16 & $\begin{array}{l}\text { intensively } \\
\text { managed } \\
\text { grassland }\end{array}$ & $\begin{array}{l}2005 \text { and } 2006 \\
\text { some cows }\end{array}$ & $12( \pm 20 \%)$ & $300( \pm 90)$ & $88( \pm 16)$ \\
\hline $\mathrm{St}^{1}$ & $0.45( \pm 0.35)$ & 12 & 79 & & 5 & 16 & $\begin{array}{l}\text { extensively } \\
\text { managed } \\
\text { hayfield }\end{array}$ & $\begin{array}{l}\text { young cattle } \\
\text { few days per } \\
\text { year }\end{array}$ & $10( \pm 20 \%)$ & 0 & 0 \\
\hline $\mathrm{Ho}^{1}$ & $0.25( \pm 0.20)$ & 2.1 & 60 & 25 & 10 & 5 & $\begin{array}{l}\text { former } \\
\text { managed } \\
\text { area under } \\
\text { restoration }\end{array}$ & none & 0 & 0 & 0 \\
\hline
\end{tabular}

${ }^{1}$ Ou: Oukoop; St: Stein; Ho: Horstermeer.

2 Values related to management are averaged over the years 2006, 2007 and 2008 and are based on farmers' records.

* From Dutch Peat Soil Map 2005 (www2.hetlnvloket.nl) and point measurements.

** Based on field measurements combined with areal photographs and the Top10Vector database.

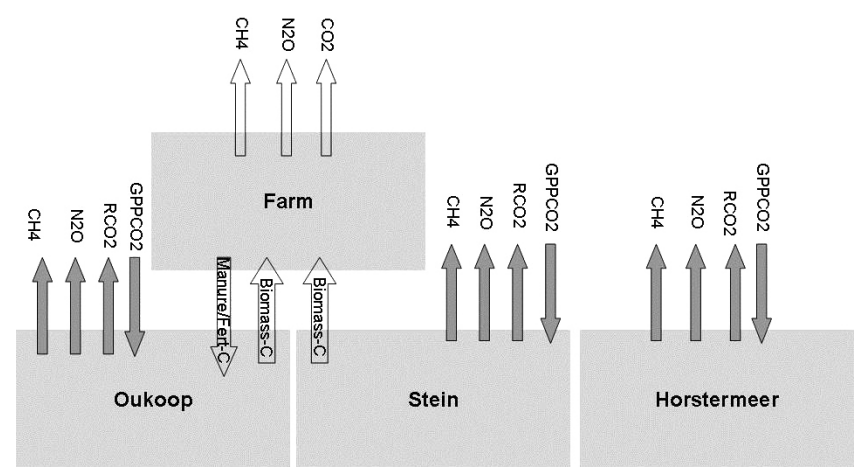

Figure 1. Ecosystem and farm-based GHG fluxes $\left(\mathrm{CO}_{2}\right.$ respiration $\left(\mathrm{RCO}_{2}\right), \mathrm{CO}_{2}$ gross primary production or photosynthesis $\left(\mathrm{GPPCO}_{2}\right), \mathrm{CH}_{4}$ and $\left.\mathrm{N}_{2} \mathrm{O}\right)$ and carbon fluxes $\left(\mathrm{CO}_{2}-\mathrm{C}\right), \mathrm{CH}_{4}-\mathrm{C}$, manure and fertilizer $\mathrm{C}$, biomass $\mathrm{C}$ that are being considered in the current study for Oukoop, Stein and Horstermeer. White arrows are farm-related fluxes and dark-grey arrows are ecosystem fluxes.

are kept on the farm. Manure and fertilizers are applied four or five times annually in the period of February to September. The area has a clayey peat or peaty clay top layer of about $0.25 \mathrm{~m}$ thickness on a $12 \mathrm{~m}$ thick peat layer on a mineral subsoil. Sixteen percent of the total polder is open water (drainage ditches, small ponds, shallow lakes), $5 \%$ borders (water-saturated) edges and the remaining part consists of relatively dry fields with a dynamic water table of mean annual depth of $0.55 \mathrm{~m}$. The dominant grass species are Lolium perenne and Poa trivialis.

The Stein site ( $\mathrm{St}$ ) is an extensively managed grassland polder on peat $4 \mathrm{~km}$ southwest of the Oukoop site (lat. $52^{\circ} 01^{\prime} \mathrm{N}$, long. $4^{\circ} 46^{\prime} \mathrm{E}$; altitude $-1.7 \mathrm{~m}$ a.s.1.). The area has been managed as a meadow bird reserve since 2001, which implies that no manure or artificial fertilizers have been applied ever since and that management only comprises the removal of above-ground biomass three times a year. The
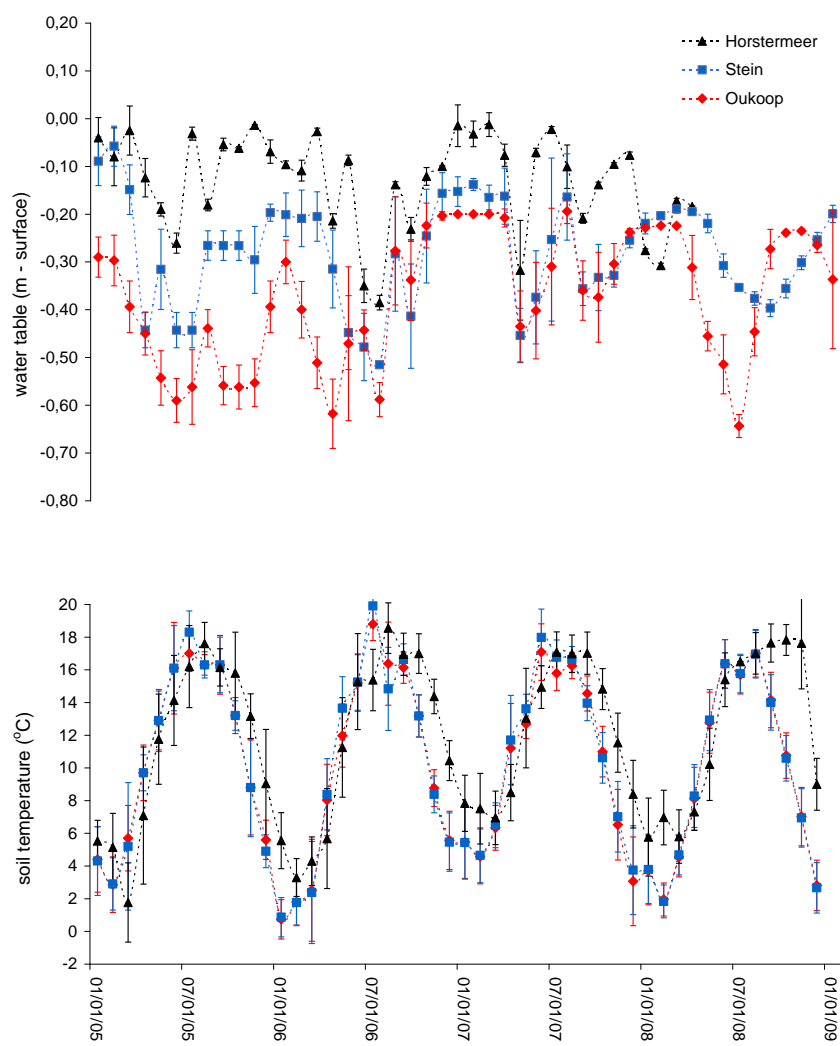

Figure 2. Monthly averages for water table and soil temperature for Oukoop (red), Stein (blue) and Horstermeer (black) for the period January 2005-December 2008. The error bars show the standard deviation around the mean.

polder was intensively used for grass production in the same way as the Oukoop polder before it gradually became a meadow bird reserve. The area has the same soil characteristics as the Oukoop site, and land use history was similar before Stein was taken out of production. The Stein site has 
had a dynamic water table since 2006, with high water tables in winter and low water tables in summer; the ground water table is on average $0.45 \mathrm{~m}$ below field level. The proportions of land and water are similar to the Oukoop site (16\% open water, $5 \%$ water-saturated borders, $79 \%$ relatively dry land). The dominating plant species were Lolium perenne and Poa triviales, but over time Anthoxantum odoratum and Rumex acetosa have become more abundant.

The Horstermeer site (Ho) is a grassland/wetland polder on peat in a former intensively used dairy farm area in the centre of the Netherlands (lat. $52^{\circ} 02^{\prime} \mathrm{N}$, long. $5^{\circ} 04^{\prime} \mathrm{E}$; altitude $-2.2 \mathrm{~m}$ a.s.l.) located about $40 \mathrm{~km}$ northeast from Oukoop and Stein. The site was abandoned in 1998 and has not been exploited agriculturally ever since. The management was quite similar to that of Stein and Oukoop until abandonment. After abandonment, the ditch water table artificially raised by humans to approximately $0.10 \mathrm{~m}$ below the land surface. The vegetation has developed towards a semi-natural grassland. Five percent of the area is open water (ditches), $10 \%$ is year-round saturated soil (mostly along the ditches), $25 \%$ is relatively wet soils and $60 \%$ is relatively dry land, with a fluctuating ground water table (between 0 and $0.40 \mathrm{~m}$ below the soils surface, $0.20 \mathrm{~m}$ annual average) with a dry top layer during the largest part of the year. Except for ditch water table regulation, no management takes place. Dominant species are Holcus lanatus, Phalaris arundinacea, Glyceria fluitans, reeds and high forbs.

\subsection{Eddy covariance measurements}

In the three sites the eddy covariance systems covered a heterogeneous landscape of fields, edges and drainage ditches as described, but excluded possible GHG hotspots such as farms and manure storages. No obstacles were placed in such a way that it could influence the fluxes measured.

\subsubsection{Instrumentation eddy covariance $\mathrm{CO}_{2}$}

Eddy covariance flux measurements of $\mathrm{CO}_{2}$ in the sites were performed with a $10 \mathrm{~Hz}$ frequency, with an averaging time of $30 \mathrm{~min}$. Flux systems for $\mathrm{CO}_{2}$ consisted of a sonic anemometer and a fast-response $\mathrm{CO}_{2}-\mathrm{H}_{2} \mathrm{O}$ open-path gas analyser placed immediately below or next to the sonic anemometer. Instrumentation differed per site and full details of all eddy-covariance-related instruments as well as other micrometeorological measurements are for each site given in Table 2.

\subsubsection{Instrumentation eddy covariance $\mathrm{CH}_{4}$ and $\mathrm{N}_{2} \mathrm{O}$}

For the $\mathrm{CH}_{4}$ and $\mathrm{N}_{2} \mathrm{O}$ eddy covariance measurements in Oukoop, a three-dimensional sonic anemometer and a quantum cascade laser (QCL) spectrometer were used. First, the time average of $w$ (vertical wind velocity in $\mathrm{m} \mathrm{s}^{-1}$ ) and $c$ (gas concentration in $\mathrm{ppb}$ ) was determined using a running mean filter (e.g. Aubinet et al., 2000; Lee et al., 2004). Then, the covariances were calculated using a running mean filter set at $120 \mathrm{~s}$ (avoiding laser drifts) and an averaging time of $30 \mathrm{~min}$ was used. The electronic sampling frequency of the QCL spectrometer was not exactly uniform and the QCL does not produce equidistance data; however, the average time between two samples was about $0.11 \mathrm{~s}$. The sonic anemometer produced a uniform sampling rate of $20.88 \mathrm{~Hz}$. The data acquisition program stored both the QCL spectrometer and sonic anemometer data in the same file at $20.88 \mathrm{~Hz}$ using the last measured concentration value (for further explanation, the reader is referred to Kroon et al., 2007).

\subsubsection{Data processing of $\mathrm{CO}_{2}$}

For $\mathrm{CO}_{2}$, data processing was applied according to the standardized EUROFLUX protocol for $\mathrm{CO}_{2}$ measurements at all three sites. Footprint analysis to determine the origin of fluxes and homogeneity of the resulting calculated footprint was performed according to Kormann and Meixner (2001) and/or Schuepp et al. (1990). For Oukoop and Stein, measured emissions detected by the systems always originated from the sites; in Horstermeer this was not the case, but if more than $70 \%$ of the flux originated from the site, the data were accepted. In addition, in Horstermeer, the method of Nakai et al. (2006) was used to apply the angle-of-attackdependent calibration for the sonic anemometer (Gash and Dolman, 2003; Van der Molen et al., 2004). In all three sites, data sets were filtered for spikes and poor-quality data due to temporary frost and dew or moisture formation on the open-path gas analyser sensor head. This resulted in rejection of up to around $40 \%$ for poor quality for the Oukoop and Stein sites and between 30 and $40 \%$ for the Horstermeer site. Storage fluxes were calculated and corrected according to Hollinger et al. (1994). The energy balance closure was between 82 and $97 \%$ for the three sites. Detailed information about the corrections that were required for the $\mathrm{CO}_{2}$ measurements is given in Table 3.

\subsubsection{Data processing $\mathrm{CH}_{4}$ and $\mathrm{N}_{2} \mathrm{O}$}

For $\mathrm{CH}_{4}$ and $\mathrm{N}_{2} \mathrm{O}$ the data processing consisted of several corrections and gap-filling procedures. The footprint was checked by a footprint model (Kormann and Meixner, 2001). The data were flagged using the instationary test of Foken and Wichura (1996). The covariances were corrected for tilt error using the natural wind coordinate system (e.g. McMillen, 1988; Lee et al., 2004). The exact delay time was determined using circular correlation (Kroon et al., 2007). A low- and high-frequency response correction and Webb correction were applied (only for samples where inlet air was not dried) as well as a two-point calibration factor based on weekly calibrations for correcting the absolute concentration values. Furthermore, the storage term was added to the eddy covariance flux term. For more detailed information about the data processing for the $\mathrm{CH}_{4}$ and $\mathrm{N}_{2} \mathrm{O}$ 
eddy covariance systems, the reader is referred to Kroon et al. (2010a).

\subsubsection{Gap-filling models}

Regressions models are developed for the three sites to fill the data gaps that resulted from instrument failure and/or bad data and for determining annual balances. These site-specific regression models for the chamber measurements differed per land form element (field, ditch edge, ditch) and per GHG; for eddy covariance measurements they covered the entire landscape. An overview of all models, procedures and model parameters used is given in Supplement S1. See also Veenendaal et al. (2007), Hendriks et al. (2007), Kroon et al. (2009, 2010a, b, c) and Schrier-Uijl et al. (2009, 2010, 2011) for additional details on the models that were used.

$\mathrm{CO}_{2}$ respiration in the three sites is described as a function of soil temperature by using the Arrhenius relation (Lloyd and Taylor, 2004; Supplement S1) based on night-time eddy covariance measurements. This allowed for gap filling of night-time gaps and partitioning of daytime fluxes into photosynthesis and respiration components since soil temperature is a physically based parameter and is closely related to ecosystem respiration (e.g. Miranda et al., 1997; Veenendaal et al., 2007). In all three sites, daytime fluxes were modelled using a Michaelis-Menten approach with incoming photosynthetically active radiation (e.g. Veenendaal et al., 2007). If gaps (both day- and night-time) were shorter than a few hours, data were interpolated.

For $\mathrm{CH}_{4}$ emission calculations at Oukoop, a site-specific multivariate regression model, including soil temperature and wind velocity is used. The parameters together explained $60 \%$ of the variability in observed daily $\mathrm{CH}_{4}$ fluxes $\left(R^{2}=\right.$ $0.63 ; P<0.0001$ ) (Kroon et al., 2010b). This regression model was used in two ways: (1) to fill data gaps and (2) to base the annual balance entirely on the regression model. The results in terms of annual $\mathrm{CH}_{4}$ emissions were similar for these two methods (average 165 and $164 \mathrm{~kg} \mathrm{CH}_{4} \mathrm{ha}^{-1} \mathrm{yr}^{-1}$, respectively).

Annual balances for $\mathrm{N}_{2} \mathrm{O}$ are calculated from four contributions: background emissions, event emissions due to fertilizer application, leaching and deposition. Background emissions are defined as emissions that occur when no fertilizer or manure is applied. The $\mathrm{N}_{2} \mathrm{O}$ background emissions were estimated by using a multivariate regression model (Kroon et al., 2010b), based on all eddy covariance fluxes except for fluxes around management events. The event emissions were calculated based on the amount of synthetic fertilizer and manure applied, and the $\mathrm{N}_{2} \mathrm{O}$ emission factor per amount of fertilizer or manure (IPCC, 2006) (see Table 5 and Kroon et al., 2010a).

The resulting data sets are used to determine annual balances, to cross-validate with the chamber measurements and to spatially upscale fluxes to the entire peatland landscape in the Netherlands.

\subsection{Chamber measurements}

Small-scale chamber measurements are performed for $\mathrm{CO}_{2}$ and $\mathrm{CH}_{4}$ over a period of 3-4 years to examine the heterogeneity of fluxes within the sites and to determine differences between the landscape elements (Schrier-Uijl et al., 2009, 2010, 2011; Hendriks, 2009). Sampling is stratified according to landscape elements (dry fields, saturated ditch edges and open water (ditches)). Similar methods and instruments were used in all three sites.

A photo-acoustic field gas monitor was used (for Oukoop and Stein an Innova type 1412 and for Horstermeer a type 1312; Innova AirTech Instruments, Ballerup, Denmark) (Table 2). The gas analyser was connected with Teflon tubes to closed opaque chambers (height $0.2 \mathrm{~m}$, diameter $0.3 \mathrm{~m}$ ) (see also Tables 2 and 3 and Supplement S1 for further details). Fans were installed in the chamber to homogenize the inside air, and two external filters were added: a soda lime filter for $\mathrm{CO}_{2}$ (when measuring $\mathrm{CH}_{4}$ ) and a silica gel filter for water vapour. To avoid disturbances in the field that influenced the concentration measurements, vegetation was not removed prior to the flux measurements and boardwalks were used in areas where the soil had a high level of water saturation.

After (airtight) placement of the measurement chamber on a cylindrical basis that was inserted into the peat soil, five gas concentration samples were taken from the headspace of this chamber over a period of 5-10 min, from which the flux (height of the chamber multiplied by $\mathrm{d} C / \mathrm{d} t$ ) was calculated. Linearity of the build-up of gas in the chamber was checked using the intercept method described by Kroon et al. (2008). Measurements with a sudden increase or decrease in gas concentration where removed from the data set.

For temporal upscaling of chamber measurements relations between natural logarithm-transformed $\mathrm{CH}_{4}$ and $\mathrm{CO}_{2}$ emissions and independent variables were determined using stepwise multiple linear regression analysis (case-wise elimination of variables, described in more detail in Schrier-Uijl et al., 2009, 2010, 2011, and Hendriks, 2009). Emissions were found to be correlated with several parameters with temperature being the most important driver for $\mathrm{CH}_{4}$ and $\mathrm{CO}_{2}$ emission in all three landscape elements for Oukoop, Stein and Horstermeer (details for Oukoop and Stein are given in Schrier-Uijl et al., 2009, 2010; the equations used are given in Supplement S1).

In the summer of 2009, an extra, intensive measurement campaign was performed on 6 large shallow lakes and 14 drainage ditches in peatlands (Schrier-Uijl et al., 2011). Also, for water bodies, cross-checks of emission values were performed by comparing eddy covariance measurements to upscaled chamber measurements within the footprint of the eddy covariance systems as before (Schrier-Uijl et al., 2009; Hendriks et al., 2009). In this paper we have compared the summer emissions from lakes to the summer emissions from fields, ditch edges and ditches. The summer fluxes have been 
Table 2. Instruments, their details and their performances used for emission estimates.

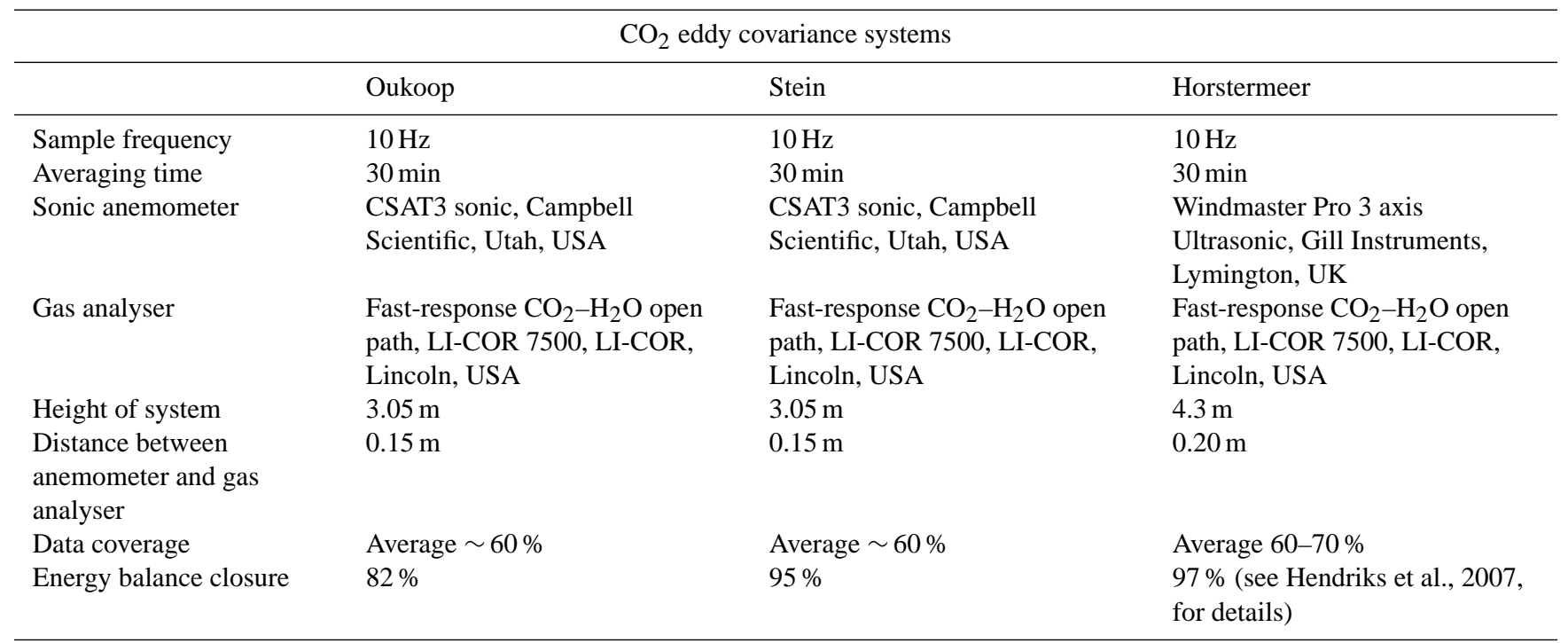

$\mathrm{CH}_{4}$ and $\mathrm{N}_{2} \mathrm{O}$ eddy covariance

\begin{tabular}{ll}
\hline $\begin{array}{l}\text { Sampling frequency sonic } \\
\text { anemometer }\end{array}$ & $20.88 \mathrm{~Hz}$ \\
$\begin{array}{l}\text { Electronic sampling fre- } \\
\text { quency QCL spectrometer }\end{array}$ & $\sim 10 \mathrm{~Hz}$ \\
$\begin{array}{l}\text { Effective bandwidth of } \\
\text { QCL spectrometer }\end{array}$ & $\sim 2 \mathrm{~Hz}$ \\
$\begin{array}{l}\text { Averaging time } \\
\text { Running mean filter time }\end{array}$ & $30 \mathrm{~min}$ \\
Sonic anemometer & $120 \mathrm{~s}$ \\
& Three-dimensional sonic model \\
& WMPRO (from 26 October 2007 \\
& to 9 September 2008) and model \\
& R3 during the rest of the \\
measurement period \\
& Gill Instruments, Lymington, UK \\
& QCL, TILDAS-76, Aerodyne \\
Research Inc., Billerica, MA, \\
Spectrometer & USA \\
& $3 \mathrm{~m}$ \\
Height of system & $0.15 \mathrm{~m}$ \\
Distance between & \\
anemometer and air inlet & \\
tube of QCL spectrometer & \\
Air inlet tube parameters & Length 25 m and diameter \\
& 0.25 in. \\
Data coverage & $48 \%$ \\
&
\end{tabular}

Chamber measurements

\begin{tabular}{llll}
\hline Gas analyser & $\begin{array}{l}\text { Photo-acoustic field gas monitor, } \\
\text { INNOVA 1412 sn, 710-113, }\end{array}$ & $\begin{array}{l}\text { Photo-acoustic field gas monitor, } \\
\text { INNOVA 1412 sn, 710-113, }\end{array}$ & $\begin{array}{l}\text { Photo-acoustic field } \\
\text { gas monitor, INNOVA 1312 } \\
\text { ENMO services, Belgium }\end{array}$ \\
$\begin{array}{ll}\text { ENMO services, Belgium } \\
\text { Sample frequency }\end{array}$ & $\begin{array}{l}\text { Every 14 days in summer to } \\
\text { every 30 days in winter }\end{array}$ & $\begin{array}{l}\text { Every 14 days in summer to } \\
\text { every 30 days in winter }\end{array}$ & $\begin{array}{l}\text { Every 14 days in summer to } \\
\text { every 30 days in winter }\end{array}$ \\
\hline
\end{tabular}


Table 2. Continued.

\begin{tabular}{|c|c|c|c|}
\hline \multicolumn{4}{|c|}{ Other measurements } \\
\hline $\begin{array}{l}\text { Incoming and reflected } \\
\text { shortwave radiation }\end{array}$ & $\begin{array}{l}\text { Kipp \& Zonen, Delft, } \\
\text { the Netherlands }\end{array}$ & $\begin{array}{l}\text { Kipp \& Zonen, Delft, } \\
\text { the Netherlands }\end{array}$ & $\begin{array}{l}\text { Kipp \& Zonen, Delft, } \\
\text { the Netherlands }\end{array}$ \\
\hline $\begin{array}{l}\text { Photosynthetic photon } \\
\text { flux density }\end{array}$ & Parlite, Kipp \& Zonen & Parlite, Kipp \& Zonen & Not measured \\
\hline Wind speed & Csat3 (Campbell Scientific Ltd.) & Csat3 (Campbell Scientific Ltd.) & $\begin{array}{l}\text { Cup anemometers, Vector Instru- } \\
\text { ments, model A100M/A100ML }\end{array}$ \\
\hline \multirow[t]{2}{*}{ Soil temperature } & Thermistor probes (Campbell & Thermistor probes (Campbell & Thermistor probes (Campbell \\
\hline & Scientific Ltd., model 107) & Scientific Ltd., model 107) & Scientific Ltd., model 107) \\
\hline Soil heat flux & Delft, Netherlands & Delft, Netherlands & Delft, Netherlands \\
\hline \multirow[t]{2}{*}{ Precipitation } & Tipping bucket rain gauge, & Tipping bucket rain gauge, & Tipping bucket rain gauge, \\
\hline & $\begin{array}{l}\text { Young, Traverse City, Michigan, } \\
\text { USA }\end{array}$ & $\begin{array}{l}\text { Young, Traverse City, Michigan, } \\
\text { USA }\end{array}$ & $\begin{array}{l}\text { Campbell Scientific Ltd., model } \\
\text { ARG100 }\end{array}$ \\
\hline Net radiation & Campbell Scientific, Q10 & Campbell Scientific, Q10 & Campbell Scientific, Q10 \\
\hline $\begin{array}{l}\text { Air temperature and } \\
\text { humidity }\end{array}$ & $\begin{array}{l}\text { HMP 45a, Vaisala, Uppsala, } \\
\text { Sweden }\end{array}$ & $\begin{array}{l}\text { HMP 45a, Vaisala, Uppsala, } \\
\text { Sweden }\end{array}$ & $\begin{array}{l}\text { Fast-response chromel- } \\
\text { constantan thermocouple, } \\
\text { Vrije Universiteit Amsterdam, } \\
\text { Netherlands }\end{array}$ \\
\hline
\end{tabular}

shown to represent around $70 \%$ of the annual $\mathrm{CH}_{4}$ emissions from drainage ditches (Schrier-Uijl et al., 2010).

The resulting data sets are used to stratify the area, to determine annual balances, to cross-validate with the eddy covariance measurements and to spatially upscale fluxes to the polder landscape.

\subsection{Additional meteorological measurements}

Each site was equipped with micrometeorological sensors to measure short- and longwave radiation, photosynthetic photon flux density, air temperature and humidity, and air pressure.

At each site, soil heat flux plates and soil temperature sensors were installed at depths of 0.02, 0.04, 0.08, 0.16 and $0.32 \mathrm{~m}$ and soil moisture probes at depths of $0.10,0.20$ and $0.30 \mathrm{~m}$ These systems provided $30 \mathrm{~min}$ values for soil heat fluxes, soil temperature, soil moisture and water table. In addition, soil temperature, water temperature and soil moisture content were recorded during each chamber measurement for the same reason. A summary of instruments and their details are given in Table 2 .

\subsection{Additional analyses}

At the start and the end of the experiments (2005 and 2008), soils were sampled and analysed for $\mathrm{C}$ and $\mathrm{N}$ content, organic matter, $\mathrm{NO}^{3-}, \mathrm{NH}^{4+}, \mathrm{PO}_{4}^{3-}$ and $\mathrm{pH}$ to check the similarity of soils. Water from drainage ditches and lakes was sampled for $\mathrm{pH}, \mathrm{C}$ content (not for Horstermeer), $\mathrm{N}$ content (not for Horstermeer), organic matter, $\mathrm{NO}_{3}^{-}, \mathrm{NH}_{4}^{+}, \mathrm{PO}_{4}^{3-}$, $\mathrm{SO}_{4}^{2-}, \mathrm{Fe}^{2+}$, dissolved $\mathrm{CH}_{4}$, oxygen saturation and electrical conductivity, as to allow for multivariate regression analyses and determination of the most important driving variable(s) of open water $\mathrm{CH}_{4}$ and $\mathrm{CO}_{2}$ emissions. Well-stirred samples of slurry manure were sampled just before manure application in the Oukoop site and were analysed for dry matter and C content (Veenendaal et al., 2007). Vegetation height was measured every 3-4 four weeks with a disc pasture meter (Eijkelkamp Giesbeek, The Netherlands) to determine above-ground biomass and biomass removal using a site-specific empirical linear relationship between vegetation height and biomass weight (dry biomass $(\mathrm{g})=29.1 \times$ disc height $\left.(\mathrm{cm})+50.2 ; R^{2}=0.84 ; n=51\right)$ (Veenendaal et al., 2007). The calculated biomass production data were found to be in agreement with the grass-production data provided by the farmer. 
Table 3. Post processing details: corrections and quality checks.

\begin{tabular}{|c|c|c|c|}
\hline \multicolumn{4}{|c|}{ Processing of $\mathrm{CO}_{2}$ Eddy Covariance data following the EUROFLUX protocol (details in Aubinet et al., 2000) } \\
\hline $\begin{array}{l}\text { Spikes \& outliers and bad } \\
\text { data (e.g. due to frost, dew } \\
\text { and moisture formation) }\end{array}$ & $\begin{array}{l}\text { Quality control criteria according } \\
\text { to Foken and Wichura (1996) as } \\
\text { signalled by processing software } \\
\text { and filter on spikes in raw data } \\
\text { (see Veenendaal et al., 2007, for } \\
\text { ranges) }\end{array}$ & $\begin{array}{l}\text { Quality control criteria according } \\
\text { to Foken and Wichura (1996) as } \\
\text { signalled by processing software } \\
\text { and filter on spikes in raw data } \\
\text { (see Veenendaal et al., 2007, for } \\
\text { ranges) }\end{array}$ & $\begin{array}{l}\text { Quality filter and stationary test; } \\
\text { see Hendriks et al. (2007) for } \\
\text { ranges }\end{array}$ \\
\hline Webb correction & Following Webb et al. (1980) & Following Webb et al. (1980) & Following Webb et al. (1980) \\
\hline Frequency losses & Leuning and King (1992) & Leuning and King (1992) & Leuning and King (1992) \\
\hline $\begin{array}{l}\text { Linear detrending and } \\
\text { rotation to the local } \\
\text { streamline }\end{array}$ & Baldocchi et al. (2001) & Baldocchi et al. (2001) & Baldocchi et al. (2001) \\
\hline Footprint analysis & $\begin{array}{l}\text { Schuepp et al. (1990) and } \\
\text { Kormann and Meixner (2001) }\end{array}$ & $\begin{array}{l}\text { Schuepp et al. (1990) and } \\
\text { Kormann and Meixner (2001) }\end{array}$ & Schuepp et al. (1990) \\
\hline
\end{tabular}

\subsection{Estimates of GHG balances and carbon balances}

The ecosystem GHG balance of each experimental site was calculated for 3 years by summation of the net ecosystem exchange of $\mathrm{CO}_{2}, \mathrm{CH}_{4}$ and $\mathrm{N}_{2} \mathrm{O}$ using the global warming potential (GWP) of each gas at the 100-year time horizon (IPCC, 2007). Thus

$\mathrm{NEE}_{\mathrm{GHG}}=\mathrm{NEE}_{\mathrm{CO}_{2}}+25 \mathrm{NEE}_{\mathrm{CH}_{4}}+298 \mathrm{NEE}_{\mathrm{N}_{2} \mathrm{O}}$

where 25 and 298 are the global warming potentials of $\mathrm{CH}_{4}$ and $\mathrm{N}_{2} \mathrm{O}$ for a 100 -year time horizon.

For Oukoop and Stein, the farm-related C and GHG fluxes were added to the ecosystem fluxes as shown in Fig. 2. A detailed overview of the fluxes that are considered in the Oukoop site is given in Fig. 3. Since part of the grass harvested in Stein was fed to the cows in Oukoop, one-third of the farm-based $\mathrm{CO}_{2}$ and $\mathrm{CH}_{4}$ emissions was allocated to Stein and two-thirds of these fluxes to Oukoop.

The ecosystem $\mathrm{CO}_{2}$ photosynthesis and respiration components (see Fig. 2 and arrows 5, 6 and 7 in Fig. 3) were determined by using chambers and eddy covariance. Farmbased $\mathrm{CO}_{2}$ emissions (see Fig. 2 and arrows 1 and 3 in Fig. 3) were estimated from the amount of biomass $\mathrm{C}$ imported into the farm subtracted by the amount of manure $\mathrm{C}$ added on the fields and the amount of $\mathrm{C}$ emitted as $\mathrm{CH}_{4}$. A production efficiency (the amount of energy intake that is transferred into meat or milk) of $7 \%$ for large mammals, is used (Van Raamsdonk et al., 2007; Nieveen et al., 2005; Guinand-Flament et al., 2007).

Ecosystem $\mathrm{CH}_{4}$ emissions were determined by using chambers and eddy covariance (see Fig. 2 and arrow 8 in Fig. 3). Farm-based $\mathrm{CH}_{4}$ emissions (see Fig. 2 and arrows 2

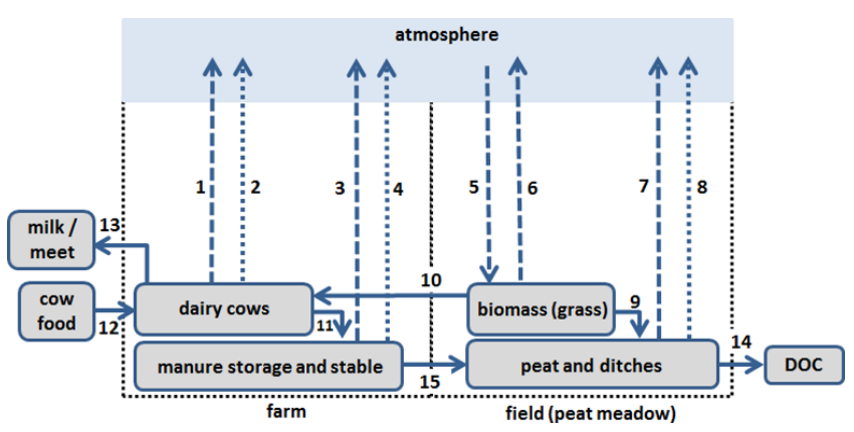

Figure 3. System boundaries of the intensively manage area Oukoop. Arrows are $\mathrm{C}$ flows, dotted arrows $(2,4,8)$ are $\mathrm{CH}_{4}$ fluxes and striped arrows $(1,3,5,6,7)$ are $\mathrm{CO}_{2}$ fluxes (autotrophic and heterotrophic respiration $-R_{\mathrm{CO}_{2}}$ auto and $R_{\mathrm{CO}_{2}}$, respectively - and photosynthesis $\left(\mathrm{GEP}_{\mathrm{CO}_{2}}\right)$ ). Arrow 9 represents the grass $\mathrm{C}$ flux into the soil and arrow 10 as hay for cow feed. Arrows 11 (cow manure), 12 (cow food), 13 (meat and milk), 14 (dissolved organic carbon (DOC)) and 15 (manure application on fields) represent the other $\mathrm{C}$ fluxes that have been considered in this study. Arrows 9, 12, 13 and 14 have been considered negligible relative to the other sources and sinks.

and 4 in Fig. 3) from the cattle and the stable were estimated following the emission factor approach described by Hensen et al. (2006):

$$
\begin{aligned}
E_{\mathrm{CH}_{4} \text { farm }} & =N_{\text {dairy } E_{\mathrm{d}}}+N_{\text {heifer } E_{\mathrm{y}}}+N_{\text {Calves } E_{\mathrm{c}}}+A_{\text {manure } E_{\mathrm{m}}}, \\
& +A_{\mathrm{FYMEf}}
\end{aligned}
$$

with $N$ the number of animals (number of dairy cows: 65; number of heifers: 20; number of calves: 10), and the amount of manure or farmyard manure (volume 
of manure storage: $780 \mathrm{~m}^{3}$ ) and with emission factors for dairy cows $\left(E_{\mathrm{d}}\right)$, heifers $\left(E_{\mathrm{y}}\right)$, calves $\left(E_{\mathrm{c}}\right)$, manure in storages $\left(E_{\mathrm{m}}\right)$ and farmyard manure $\left(E_{\mathrm{f}}\right)$. The emission parameters were $274 \mathrm{~g} \mathrm{CH}_{4}$ day $^{-1}$ animal $^{-1}$ for cows, $170 \mathrm{~g} \mathrm{CH}_{4}$ day $^{-1}$ animal $^{-1}$ for heifers, $48 \mathrm{~g} \mathrm{CH}_{4}$ day $^{-1}$ animal $^{-1}$ for calves, $53 \mathrm{~g} \mathrm{CH}_{4}$ day $^{-1} \mathrm{~m}^{-3}$ for fertilizer and $40 \mathrm{~g} \mathrm{CH}_{4}$ day $^{-1} \mathrm{~m}^{-3}$ for farmyard manure - all $\pm 50 \%$ (Sneath et al., 2006; Van Amstel et al., 2003).

The ecosystem $\mathrm{N}_{2} \mathrm{O}$ fluxes that are shown in Fig. 1 were measured in the Oukoop site by using eddy covariance, whereas for the Stein and Horstermeer sites these components have been estimated from Velthof et al. (1997), who estimated peat $\mathrm{N}_{2} \mathrm{O}$ emissions from 2 years of measurements on similar peat soils in the same region. The farm-based $\mathrm{N}_{2} \mathrm{O}$ source strength was estimated by using the farm measurements of Hensen et al. (2006).

External $\mathrm{C}$ inputs from imported feeds and outputs through milk and meat and dissolved organic $\mathrm{C}$ losses as well as inputs from grass remains into the peat (arrows 12, 1314 and 9 in Fig. 3) in Oukoop have been considered negligible relative to the other sources and sinks (e.g. Nieveen et al., 2005; Lovett et al., 2008; Wells, 2001).

Indirect $\mathrm{C}$ losses due to leaching and run-off were measured in the Horstermeer site, but were not directly measured in the Oukoop and Stein site. Leaching in Oukoop and Stein is considered negligible according IPCC (2006), and Hendriks et al. (2007) reported that leaching in Horstermeer was also negligible.

\subsection{Upscaling of fluxes to regional scale}

To be able to scale the site fluxes up to the entire western peatland area of the Netherlands (115000 ha), a detailed database was compiled using the topographic vector-based Top10Vector database (TDN, 2006), a field inventory (Nol et al., 2008) and databases of Dutch natural peatlands (Natuurmonumenten, Staatsbosbeheer, Provinciale landschappen). The resulting database distinguishes between intensively and extensively managed peatland and ditches and ditch edges within these peatlands. Under the assumption that fluxes measured in the intensively managed area and the extensively managed area in this study are representative for the Dutch western peatland area, the emissions have been extrapolated to a larger area. Table 4 shows the areas of the land use and landscape elements.

\section{Results}

\subsection{Carbon dioxide balance}

Figure 4 shows the daily measured $\mathrm{CO}_{2}$ emission for all three sites for the period 2005-2008 and the respiration and photosynthesis for each year. The restored site was a $\mathrm{CO}_{2}$ sink in all years (range -2.9 to $-5.3 \mathrm{~g} \mathrm{CO}_{2} \mathrm{~m}^{-2} \mathrm{~d}^{-1}$ ), with periods of a net (small) release in late winter/early spring pe-
Table 4. Landscape elements in the Dutch peatlands.

\begin{tabular}{lrr}
\hline $\begin{array}{l}\text { Landscape element/ } \\
\text { land use }\end{array}$ & $\begin{array}{r}\text { Surface } \\
\text { area (ha) }\end{array}$ & $\begin{array}{r}\text { Surface } \\
\text { area (\%) }\end{array}$ \\
\hline Grassland/intensively managed & 78375 & $68 \%$ \\
Grassland/extensively managed & 8786 & $8 \%$ \\
Water & 6717 & $6 \%$ \\
Urban area (incl. greenhouses) & 983 & $1 \%$ \\
Roads & 4490 & $4 \%$ \\
Forest & 2716 & $2 \%$ \\
Cropland & 1818 & $2 \%$ \\
Other land use & 11258 & $10 \%$ \\
\hline Total & 115142 & $100 \%$ \\
\hline
\end{tabular}

${ }^{1}$ n.e. stands for not estimated

Kadaster, 2010. Product information TOP10vector (in Dutch).

Topografische Dienst Kadaster, Emmen, the Netherlands. Available at

http://www.tdn.nl/ (last access: 3 May 2010). The geometric uncertainty of the Top10Vector database is estimated to be $2 \mathrm{~m}$ (Van Buren et al., 2003).

Further details on TOP10vector calculations for the landscape elements in Dutch peatlands are provided in Nol et al. (2008).

riods and with net uptake in the rest of the year. The managed sites appeared to be sources of $\mathrm{CO}_{2}$ in all years, except for Oukoop being a marginal sink (not significantly different from zero) for $\mathrm{CO}_{2}$ in 2007, which was a relatively wet and cold year, and Stein being a marginal sink of $\mathrm{CO}_{2}$ in 2005 (range -0.47 to +2.05 and -0.24 to $+2.16 \mathrm{~g} \mathrm{CO}_{2} \mathrm{~m}^{-2} \mathrm{~d}^{-1}$ for Oukoop and Stein, respectively).

Temporal variability of the annual net ecosystem exchange (NEE) (excluding management related fluxes) was high, but NEE of $\mathrm{CO}_{2}$ in the three areas showed a clear difference between the managed (Oukoop and Stein, net release) and the restored (Horstermeer, net uptake) peatlands (Table 5). The restored peatland (Horstermeer) had an average $\mathrm{CO}_{2}$ uptake of $3.8 \mathrm{~g} \mathrm{CO}_{2} \mathrm{~m}^{-2} \mathrm{~d}^{-1}$, while the two managed peatlands (Stein and Oukoop) had an average release of $1.1 \mathrm{~g} \mathrm{CO}_{2} \mathrm{~m}^{-2} \mathrm{~d}^{-1}$ over a 4-year period. Inter-annual variability was high, but seasonal trends were the same for each year (Fig. 4). In the years 2006 and 2008 the managed systems had the highest release of $\mathrm{CO}_{2}$, while the restored system had the highest uptake in the year 2007.

Monthly $\mathrm{CO}_{2}$ values show that the difference between the managed areas with low water tables and the restored area with high water table is largest in the growing season (Fig. 5). The former agricultural peatland, Horstermeer, with its restored vegetation is a large sink in this period while Oukoop and Stein are only minor sinks.

Farm-based $\mathrm{CO}_{2}$ emissions were calculated from the biomass $\mathrm{C}$ fed to the cows on the farm and the transformation to manure $\mathrm{C}$. With an assimilation efficiency of $7 \%$ for large mammals, and $142 \mathrm{~g} \mathrm{C} \mathrm{m}^{-2} \mathrm{yr}^{-1}$ exported as manure to the fields, the total farm-based $\mathrm{CO}_{2}$ release for Oukoop is estimated to be $1.9 \mathrm{~g} \mathrm{CO}_{2} \mathrm{~m}^{-2} \mathrm{~d}^{-1}$. 
Table 5. Terrestrial carbon dioxide flux estimates $\left(\mathrm{kg} \mathrm{CO}_{2} \mathrm{~m}^{-2} \mathrm{yr}^{-1}\right)$ measured by means of eddy covariance in the period $2005-2008$ for the intensively managed production grassland on peat, Oukoop $(\mathrm{Ou})$; the extensively managed hayfield on peat, Stein (St); and the restored former agricultural peatland, Horstermeer (Ho). Fluxes from removed biomass are not included in this table.

\begin{tabular}{lrrrrrr}
\hline Site & \multicolumn{3}{l}{$\begin{array}{l}\text { Carbon dioxide } \mathrm{NEE}^{1} \text { per year }\left(\mathrm{kg} \mathrm{CO}_{2} \mathrm{~m}^{-2} \mathrm{yr}^{-1}\right) \text {. A negative sign means } \\
\text { "ecosystem uptake". The annual variability is given within brackets as a } \\
\text { standard deviation around the annual mean. }\end{array}$} \\
\cline { 2 - 7 } & 2005 & 2006 & 2007 & 2008 & Mean & $\mathrm{SD}$ \\
\hline $\mathrm{Ou}$ & $0.4( \pm 3.0)$ & $0.7( \pm 3.0)$ & $-0.2( \pm 3.1)$ & $0.7( \pm 2.3)$ & 0.40 & 0.42 \\
$\mathrm{St}$ & $-0.09( \pm 2.6)$ & $0.8( \pm 2.1)$ & $0.3( \pm 2.2)$ & $0.8( \pm 1.9)$ & 0.43 & 0.43 \\
$\mathrm{Ho}$ & $-1.0( \pm 2.6)$ & $-1.0( \pm 2.6)$ & $-1.9( \pm 2.6)$ & $-1.5( \pm 2.5)$ & -1.35 & 0.44 \\
\hline
\end{tabular}

${ }^{1}$ NEE: net ecosystem exchange.

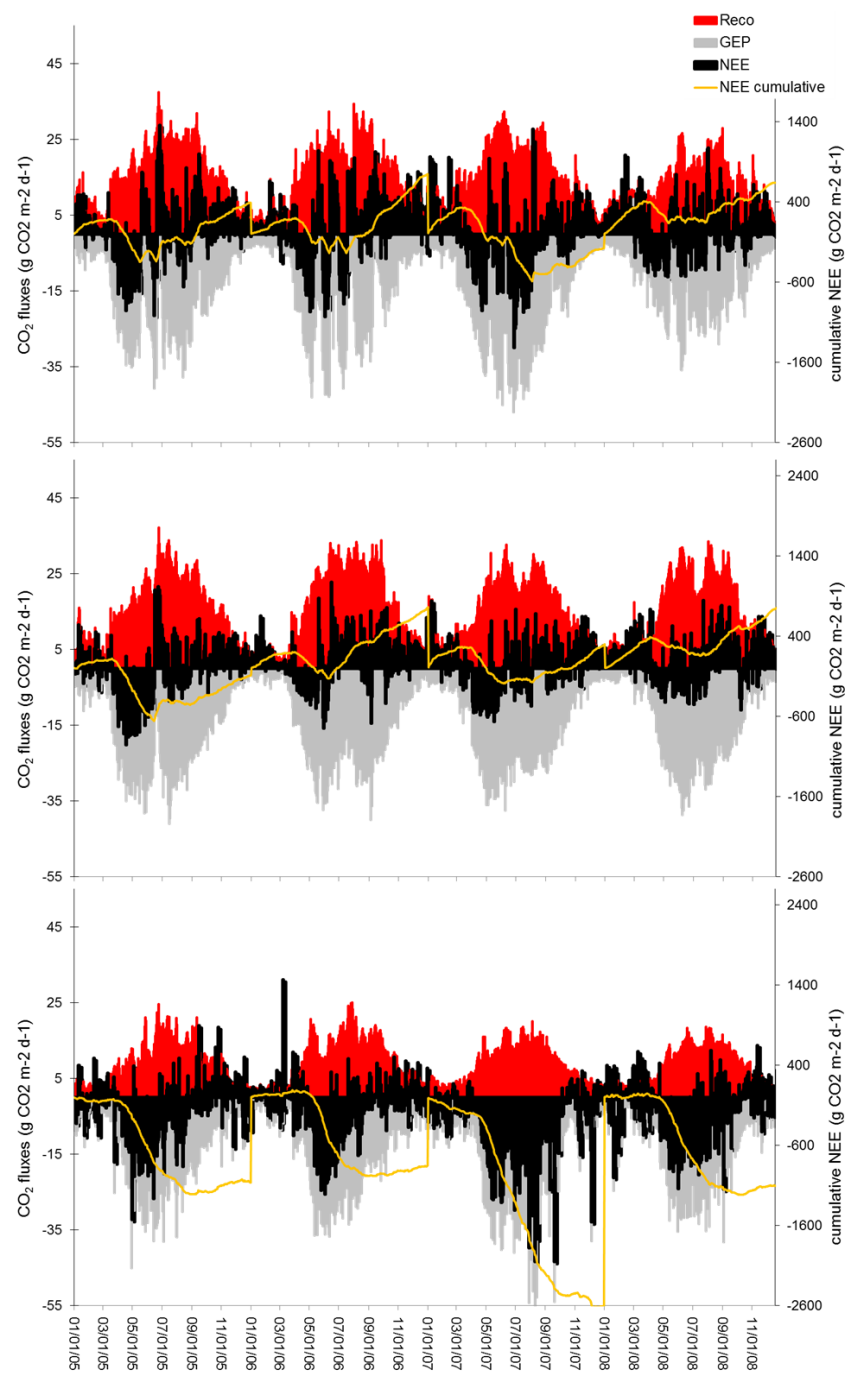

Figure 4. Daily NEE (black), respiration (red) and photosynthesis (grey) and the cumulative NEE (yellow line) in $\mathrm{g} \mathrm{CO}_{2} \mathrm{~m}^{2}$ day ${ }^{-1}$ for the Oukoop (intensively managed), Stein (extensively managed) and Horstermeer (formerly managed) peatlands, measured by means of the eddy covariance flux technique.

\subsection{Methane balance}

For all three sites, soil and water temperature were the most significant predictors of $\mathrm{CH}_{4}$ emissions and temperature is therefore used as explanatory variable to determine annual balances (Schrier-Uijl et al., 2010; Hendriks et al., 2007); for all sites the $\mathrm{CH}_{4}$ flux is calculated as $e^{a+b T}$, where $T$ is soil temperature and factors $a$ and $b$ are specific for the site and landform (field, ditch and ditch edge). Annual emissions for Oukoop and Stein averaged over 2006-2008 are 17.0 and $16.7 \mathrm{~g} \mathrm{CH}_{4} \mathrm{~m}^{-2} \mathrm{yr}^{-1}$, respectively, and those for Horstermeer averaged over 2005-2008 are $19.2 \mathrm{~g} \mathrm{CH}_{4} \mathrm{~m}^{-2} \mathrm{yr}^{-1}$. An overview of the fluxes per year is given in Table 6. Average summertime emissions over the months July and August in the measurement period are $31.3( \pm 9.5), 36.6( \pm 3.6)$ and $20.6( \pm 10.2) \mathrm{g} \mathrm{CH}_{4} \mathrm{~m}^{-2} \mathrm{yr}^{-1}$ for Oukoop, Stein and Horstermeer, respectively (Fig. 9).

Figure 6 shows the temporal variability (daily values) and the cumulative terrestrial $\mathrm{NEE}_{\mathrm{CH}_{4}}$ (including fields, saturated land and open water) over 3 years for all three sites, calculated from chamber-measurement-based regressions. For the Oukoop site, 3 years of eddy covariance measurements are also shown. Modelled emissions based on chamber measurements explain less of the temporal variability of fluxes compared to the eddy covariance measurements because only temperature is used as predictive variable. Annual cumulative $\mathrm{CH}_{4}$ values are similar for Oukoop and Stein and are higher for the Horstermeer site. The $\mathrm{CH}_{4}$ emissions varied widely with the season, reaching highest levels during summer. Spatial variability was found to be high between landscape elements within an ecosystem (Schrier-Uijl et al., 2010; Hendriks et al., 2007, 2009) and between ecosystems (this study).

Schrier-Uijl et al. (2010) reported additional farm-based emissions of 17 and $26 \mathrm{~g} \mathrm{CH}_{4} \mathrm{~m}^{-2} \mathrm{yr}^{-1}$ for Stein and Oukoop, respectively, for the years 2006, 2007 and 2008. The sum of terrestrial $\mathrm{CH}_{4}$ emissions and farm-based $\mathrm{CH}_{4}$ emissions amounted to $43.0 \mathrm{~g} \mathrm{CH}_{4} \mathrm{~m}^{-2} \mathrm{yr}^{-1}$ for Oukoop, $33.7 \mathrm{~g} \mathrm{CH}_{4} \mathrm{~m}^{-2} \mathrm{yr}^{-1}$ for Stein, and $19.2 \mathrm{~g} \mathrm{CH}_{4} \mathrm{~m}^{-2} \mathrm{yr}^{-1}$ for Horstermeer. 
Table 6. Annual methane fluxes $\left(\mathrm{g} \mathrm{CH}_{4} \mathrm{~m}^{-2} \mathrm{yr}^{-1}\right)$ (1) measured by means of the chamber method and calculated by using landscapeelement-weighted predictive relationships for Oukoop, Stein and Horstermeer and (2) measured by means of eddy covariance in the intensively managed site and modelled by using predictive relationships. Uncertainties are given within brackets and are averaged over the 3 or 4 years. Farm-based emissions are not included in this table.

\begin{tabular}{lccccc}
\hline Ecosystem & \multicolumn{4}{c}{$\begin{array}{c}\text { Annual methane fluxes } \\
\left(\mathrm{g} \mathrm{CH}_{4} \mathrm{~m}^{-2} \mathrm{yr}^{-1}\right)\end{array}$} & \begin{tabular}{c} 
Average emission \\
$\left(\mathrm{g} \mathrm{CH}_{4} \mathrm{~m}^{-2} \mathrm{yr}^{-1}\right)$ \\
\cline { 2 - 5 }
\end{tabular} \\
\cline { 2 - 5 } & 2005 & 2006 & 2007 & 2008 & Average \\
\hline Ou (chamber method) & $\mathrm{NA}^{1}$ & $20.3( \pm 48 \%)$ & $16.2( \pm 60 \%)$ & $14.6( \pm 60 \%)$ & 17.0 \\
Ou (eddy covariance method) & $\mathrm{NA}^{1}$ & $17.2( \pm 30 \%)$ & $16.6( \pm 31 \%)$ & $15.5( \pm 26 \%)$ & 16.4 \\
St (chamber method) & $\mathrm{NA}^{1}$ & $15.7( \pm 48 \%)$ & $18.0( \pm 54 \%)$ & $16.3( \pm 59 \%)$ & 16.7 \\
Ho (chamber method) & $19.1( \pm 60 \%)$ & $20.5( \pm 53 \%)$ & $19.8( \pm 48 \%)$ & $17.6( \pm 59 \%)$ & 19.2 \\
\hline
\end{tabular}

${ }^{1}$ NA: not available.
2 Spatially weighted for contribution of fields, ditches and edges.

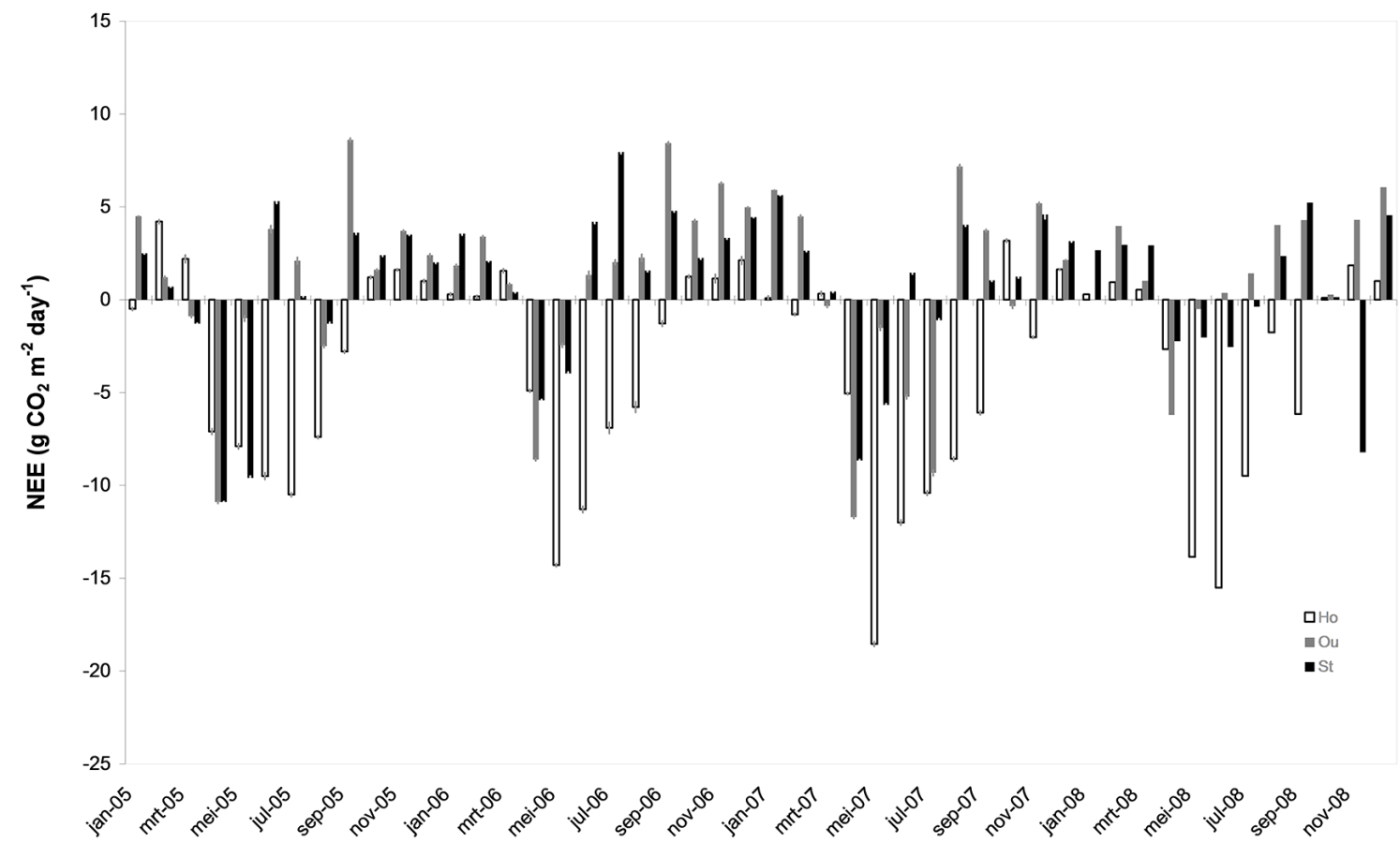

Figure 5. Averages of daily NEE calculated for each month for the three experimental sites and their standard deviations. The NEE is given on the $y$ axes in $\mathrm{g} \mathrm{CO}_{2} \mathrm{~m}^{-2} \mathrm{~d}^{-1}$ and the month numbers are given from 2005 to 2008 on the $x$ axes.

\subsection{Carbon balance}

The terrestrial $\mathrm{CO}_{2}$ source estimates of $1.1 \mathrm{~g} \mathrm{CO}_{2} \mathrm{~m}^{-2} \mathrm{~d}^{-1}$ on average over 4 years for Oukoop and Stein and $-3.8 \mathrm{~g} \mathrm{CO}_{2} \mathrm{~m}^{-2} \mathrm{~d}^{-1}$ for Horstermeer result in an average $\mathrm{C}$ source strength of $1091 \mathrm{~kg} \mathrm{Cha}^{-1} \mathrm{yr}^{-1}$ for Oukoop and Stein and $-4515 \mathrm{~kg} \mathrm{Cha}^{-1} \mathrm{yr}^{-1}$ for Horstermeer.

The average $\mathrm{CH}_{4}$ emission estimates of 17.0 and $16.7 \mathrm{~g} \mathrm{CH}_{4} \mathrm{~m}^{-2} \mathrm{yr}^{-1}$ for Oukoop and Stein, and $19.2 \mathrm{~g} \mathrm{CH}_{4} \mathrm{~m}^{-2} \mathrm{yr}^{-1}$ for Horstermeer (Table 4), result in an average $\mathrm{C}$ source strength of $127.5,125.3$ and $144.0 \mathrm{~kg} \mathrm{Cha}^{-1} \mathrm{yr}^{-1}$, respectively.
The average annual remittal of $\mathrm{C}$ through manure into the field was estimated to be $157 \mathrm{~g} \mathrm{C} \mathrm{m}^{-2}$ on average over the period 2005-2008; $64.5 \mathrm{~m}^{3} \mathrm{ha}^{-1}$ manure was applied during this period, amounting to $310 \mathrm{~kg} \mathrm{~N} \mathrm{ha}^{-1}$. Fertilizer application amounted to $88 \mathrm{~kg} \mathrm{Nha}^{-1}$ on average for the 4 years.

Removal of biomass in Oukoop was estimated to be $8.1 \mathrm{t}$ dry matter on average for 2005, 2006 and 2008, respectively, or on average a loss of $400 \mathrm{~g} \mathrm{C} \mathrm{m}^{-2} \mathrm{yr}^{-1}$. In Stein, $\mathrm{C}$ loss by biomass removal was similar in all years, estimated to be $420 \mathrm{~g} \mathrm{C} \mathrm{m}^{-2} \mathrm{yr}^{-1}$. The removed biomass was fed to the dairy cattle in Oukoop and is transformed to manure $\mathrm{C}$. With an assimilation efficiency of $7 \%$ for large mammals, $142 \mathrm{~g} \mathrm{C} \mathrm{m}^{-2} \mathrm{yr}^{-1}$ exported to the fields as manure and 


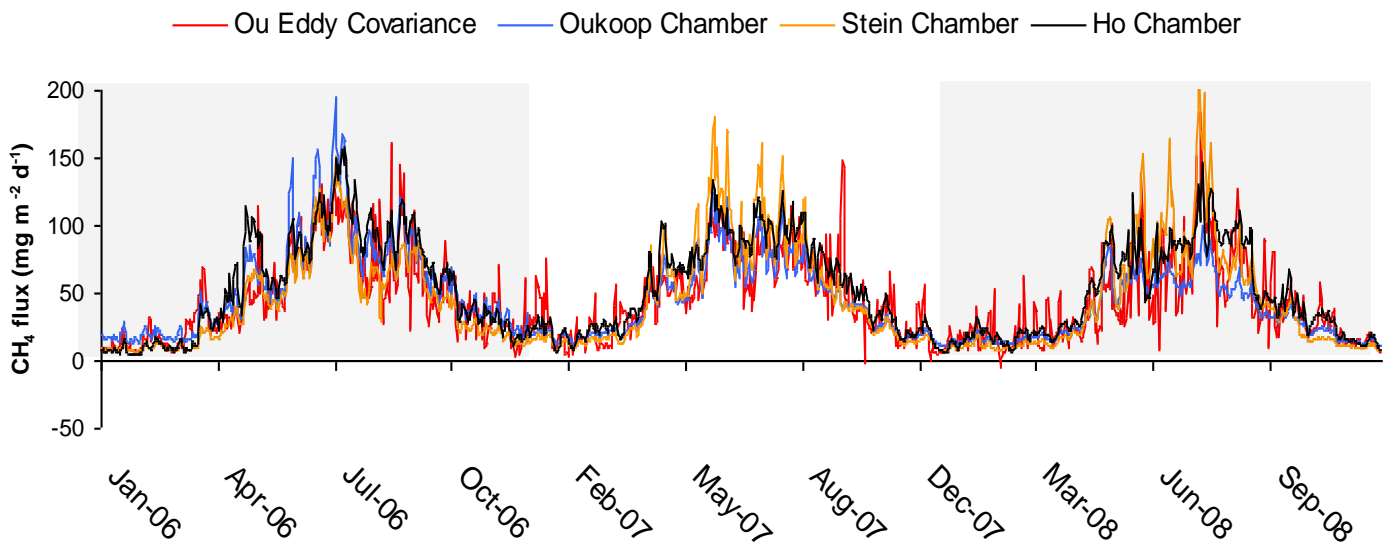

Figure 6. Temporal variability of terrestrial $\mathrm{CH}_{4}$ fluxes for the three experimental sites modelled by predictive relationships based on chamber measurements and additionally for Oukoop measured by means of continuous eddy covariance. The right-hand $y$ axis represents the cumulative $\mathrm{CH}_{4}$ flux over the 3 years. Fluxes are weighted by the contribution of each landscape element.

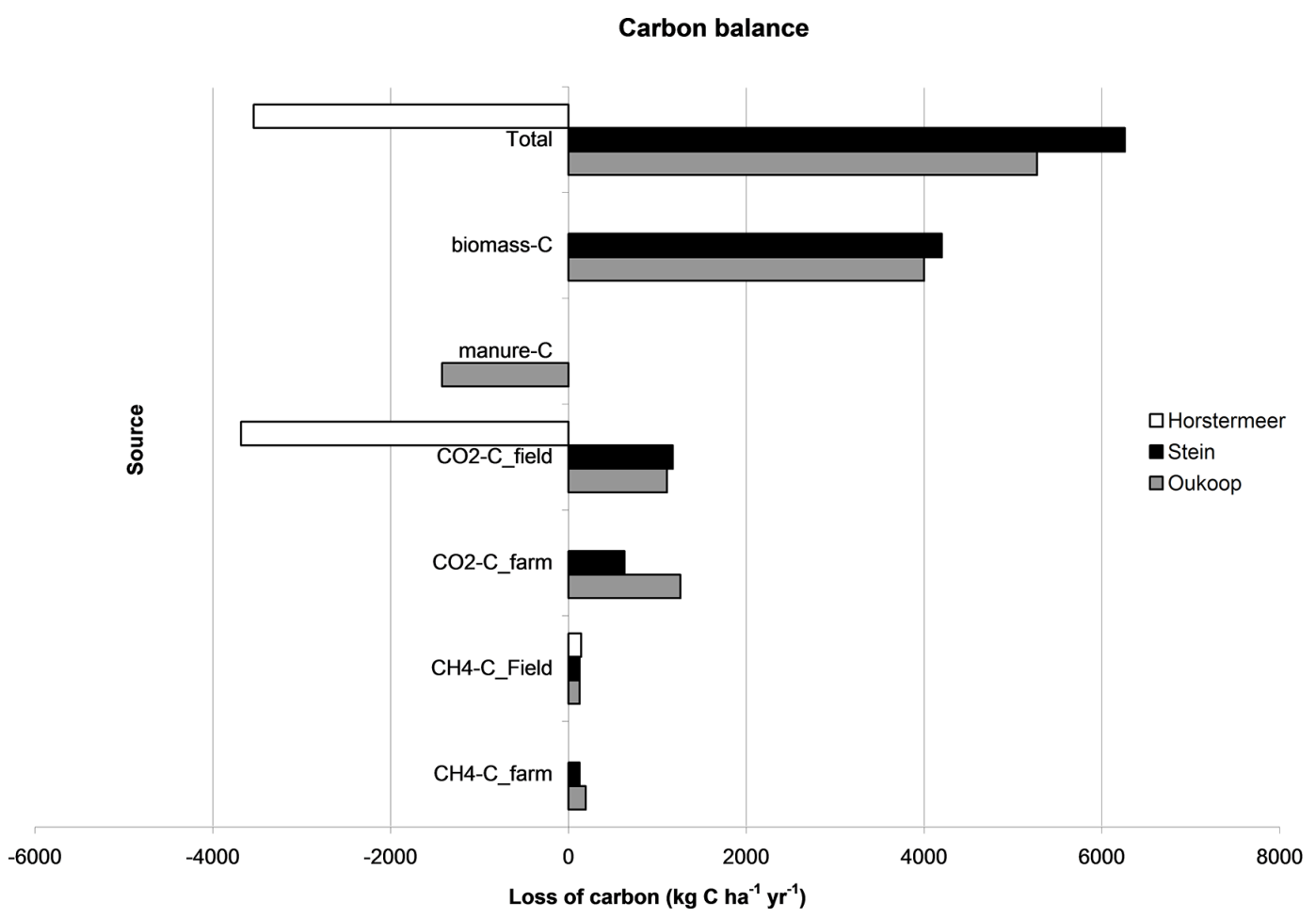

Figure 7. Summary of all considered carbon fluxes in the research areas Horstermeer (Ho), Stein (St) and Oukoop (Ou) averaged over 2005, 2006, 2007 and 2008. The annual carbon balance is presented in $\mathrm{kg} \mathrm{Cha}^{-1} \mathrm{yr}^{-1} ;(+)$ is release and (-) is uptake. The total balance consists of ecosystem fluxes $\left(\mathrm{CO}_{2}-\mathrm{C}_{-}\right.$field and $\mathrm{CH}_{4}-\mathrm{C}_{-}$field $)$and fluxes due to management $\left(\mathrm{CO}_{2}-\mathrm{C}_{-}\right.$farm, $\mathrm{CH}_{4}-\mathrm{C}_{-}$farm, biomass- $\mathrm{C}$ and manure-C) . Uncertainties around management fluxes are around 50\%. Uncertainties around ecosystem fluxes are in the range of 40-60\%.

a farm-based $\mathrm{CH}_{4}$ emission of $57 \mathrm{~g} \mathrm{C} \mathrm{m}^{-2} \mathrm{yr}^{-1}$, the farmbased $\mathrm{C}$ release will be around $0.19 \mathrm{~kg} \mathrm{~m}^{-2} \mathrm{yr}^{-1}$.

Figure 7 shows the total $\mathrm{C}$ balance for the three sites, taking into account the emissions of $\mathrm{CO}_{2}$ and $\mathrm{CH}_{4}$, manure application and biomass export as described above. The total C release in Oukoop and Stein is 5.2 and $6.3 \mathrm{Mg} \mathrm{Cha}^{-1} \mathrm{yr}^{-1}$, respectively, and the total $\mathrm{C}$ uptake in Horstermeer is
3.5 $\mathrm{MgCha}^{-1} \mathrm{yr}^{-1}$. The higher $\mathrm{C}$ release in Stein compared to Oukoop is mainly because in Oukoop manure $\mathrm{C}$ is added to the system.

\subsection{Nitrous oxide balance}

Measured cumulative NEE $\mathrm{N}_{2} \mathrm{O}$ was previously determined over a period of 3 years at the intensively managed 
site (Kroon et al., 2010b). Emissions have been separated in (1) background emissions, (2) fertilizer-related indirect (peak) emission and (3) emissions due to atmospheric deposition. In Oukoop, farm-based $\mathrm{N}_{2} \mathrm{O}$ emissions from manure storages (estimated to be $1.5 \times 10^{-2} \mathrm{~g} \mathrm{~N}_{2} \mathrm{O} \mathrm{m}^{-2} \mathrm{yr}^{-1}$ ) were also added to the total $\mathrm{N}_{2} \mathrm{O}$ balance, although they were not significant. Nitrous oxide emissions in the extensively managed site (Stein) and restored site (Horstermeer) were estimated based on Velthof et al. (1997), since the chamber setup used was not sufficient to detect the low $\mathrm{N}_{2} \mathrm{O}$ emissions in these sites. Table 7 shows all $\mathrm{N}_{2} \mathrm{O}$ flux estimates.

\subsection{Total GHG balance}

Figure 8 shows the total GHG balance of the three sites in terms of global warming potential.

Methane emissions from drainage ditches and saturated soil edges along ditches were significantly higher compared to fluxes from the relatively dry land (Schrier et al., 2010; Hendriks et al., 2007). The $\mathrm{CH}_{4}$ component in the GHG balance in the studied sites consists of outgoing fluxes only and $\mathrm{N}_{2} \mathrm{O}$ emission in the intensively managed site consists of emissions originating from fertilizer events and from background emission.

Overall, the managed peatlands acted as terrestrial GHG sources of 1.4 and $1.0 \mathrm{~kg} \mathrm{CO}_{2}$-eq m${ }^{-2} \mathrm{yr}^{-1}$ (including $\mathrm{CO}_{2}$, $\mathrm{CH}_{4}$ and $\mathrm{N}_{2} \mathrm{O}$ ), respectively, for Oukoop and Stein and the restored site acted as a GHG sink of $0.8 \mathrm{~kg} \mathrm{CO}_{2}$-eq m${ }^{-2} \mathrm{yr}^{-1}$. Ecosystem $\mathrm{N}_{2} \mathrm{O}$ emissions were dominant in the intensively managed peatland, while $\mathrm{CO}_{2}$ and $\mathrm{CH}_{4}$ dominated the ecosystem GHG balance of the extensively managed peatland. In the restored peatland, $\mathrm{CO}_{2}$ was the dominating ecosystem GHG. Adding the farm-based $\mathrm{CH}_{4}$ and $\mathrm{CO}_{2}$ emissions decreased the relative importance of $\mathrm{N}_{2} \mathrm{O}$ in the total GHG balance of the intensively managed peatland. The difference in total source strength between the intensively managed peatland and the extensively managed peatland was mainly attributed to the higher $\mathrm{N}_{2} \mathrm{O}$ emission and the higher farm-based $\mathrm{CH}_{4}$ emissions in the intensively managed site.

\subsection{Upscaling GHG emissions from Dutch peatland areas}

In the western Dutch peatland area, $68 \%$ is intensively managed grassland, $8 \%$ is extensively managed grassland or restored grassland, $6 \%$ is water (Table 8 ) and the remaining part is road or farm or has other land use. With the emission values found in this study for intensively and extensively managed peatland and the total area for both of these land uses, emission estimates are performed for the total intensively managed grassland and extensively managed and restored grasslands in the western peatland. The total emission, estimated using a time horizon of 100 years from the western peatlands, is approximately $1210 \mathrm{Gg} \mathrm{CO}_{2}$-eq (i.e. $\mathrm{kt} \mathrm{CO}_{2}$ eq). In lakes the annual $\mathrm{CO}_{2}$ emissions are estimated from summer measurements only; however, these fluxes have to be verified by performing year-round measurements and by including all three GHGs in the balance.

\section{Discussion}

\subsection{Balances}

In this paper we integrate observations on a full data set of 4 years of measurements in three peatland sites, much of which has not been reported previously. The comparisons in the present data set therefore give a full, longer term overview of this landscape study.

The three studied peatlands differed in management: a drained intensively managed grass-on-peatland area with application of fertilizer and biomass export, a drained extensively managed grass-on-peatland area with biomass export only, and a shallow drained former agricultural peatland that has been restored since 1998. Significant differences in GHG emissions have previously been reported between landscape elements within these three sites: $\mathrm{CH}_{4}$ emissions from drainage ditches and saturated soil were significantly higher compared to $\mathrm{CH}_{4}$ emissions from the relatively dry land (Schrier-Uijl et al., 2009; Hendriks et al., 2007) and $\mathrm{CH}_{4}$ fluxes from shallow lakes in the peat area contribute significantly to the GHG balance (Schrier-Uijl et al., 2010). We observed differences in management. Emissions originating from the operating farm in the intensively managed peatland were found to be important contributors to the GHG balance as well as to the $\mathrm{C}$ balance (Schrier-Uijl et al., 2009; Veenendaal et al., 2007).

Both managed experimental grass-on-peat areas, Oukoop and Stein, acted as $\mathrm{CO}_{2}$ emissions sources. Variation in $\mathrm{CO}_{2}$ emissions in Oukoop and Stein was mainly a result of management: Oukoop has the most variable NEE, which is a result of the very high frequency of mowing, grazing and manure application. Mowing results in sharp changes in NEE mainly due to a strong reduction of photosynthesis due to the abrupt removal of photosynthetic material. In Stein, management, and therefore variability in NEE, showed less variability with the first biomass removal on 15 June and the second biomass removal in September of each year. The restored site, Horstermeer, acted as a $\mathrm{CO}_{2}$ sink as no biomass is being removed from the site. The cumulative NEE shows a stable pattern with high uptake rates in spring and summer. The Horstermeer site is still being restored, and despite its abandonment in 1998, soil conditions remain eutrophic because of influx of eutrophic ground water from the surrounding area. The continuing nutrient-rich conditions generate high plant productivity and microbial activity, resulting in high $\mathrm{C}$ fluxes (both uptake and emissions) and more organic matter is accumulated than oxidized (Hendriks et al., 2009). However, development of the nutrient-rich, formerly managed system into a more nutrient-poor system with 
Table 7. Nitrous oxide flux estimates $\left(\mathrm{kg} \mathrm{N}_{2} \mathrm{Oha}^{-1} \mathrm{yr}^{-1}\right)$ and their uncertainties for the intensively managed site (Oukoop), extensively managed site (Stein) and the restored peatland (Horstermeer).

\begin{tabular}{|c|c|c|c|}
\hline Site & Source & Reference & $\begin{array}{l}\text { Total emission } \\
\left(\mathrm{kg} \mathrm{N}_{2} \mathrm{Oha}^{-1} \mathrm{yr}^{-1}\right)\end{array}$ \\
\hline \multirow[t]{4}{*}{ Oukoop } & Background emission ${ }^{1}$ & Kroon et al. (2010b) & $\begin{array}{l}\text { 2006: } 22( \pm 50 \%) \\
\text { 2007: } 21( \pm 49 \%) \\
\text { 2008: } 20( \pm 48 \%)\end{array}$ \\
\hline & Due to fertilizers ${ }^{2}$ & Kroon et al. (2010b) & \\
\hline & Due to leaching and run-off & Kroon et al. (2010b), IPCC (2006) & \\
\hline & Due to deposition & Kroon et al. (2010b), IPCC (2006) & \\
\hline Stein & Total emission & Velthof et al. (1997), IPCC (2006) & $8( \pm 100 \%)$ \\
\hline Horstermeer & Total emission & Velthof et al. (1997), IPCC (2006) & $8( \pm 100 \%)$ \\
\hline
\end{tabular}

Table 8. Estimated area and annual GHG release for the areal of intensively managed and extensively managed (mown only) or restored grasslands on peat within the total western peatland region of the Netherlands. Farm-based emissions are not included.

\begin{tabular}{|c|c|c|c|c|c|c|}
\hline \multirow[t]{2}{*}{ Ecosystem type } & \multicolumn{2}{|c|}{$\begin{array}{c}\text { Area in western } \\
\text { peatland }\end{array}$} & \multirow{2}{*}{$\begin{array}{r}\text { Total } \\
\mathrm{N}_{2} \mathrm{O} \text { emission } \\
10^{3} \mathrm{~kg} \mathrm{~N}_{2} \mathrm{O} \mathrm{yr}^{-1}\end{array}$} & \multirow{2}{*}{$\begin{array}{r}\text { Total } \\
\mathrm{CH}_{4} \text { emission } \\
10^{3} \mathrm{~kg} \mathrm{CH}_{4} \mathrm{yr}^{-1}\end{array}$} & \multirow{2}{*}{$\begin{array}{r}\text { Total } \\
\mathrm{CO}_{2} \text { emission } \\
10^{3} \mathrm{~kg} \mathrm{CO}_{2} \mathrm{yr}^{-1}\end{array}$} & \multirow{2}{*}{$\begin{array}{r}\text { Total warming } \\
\text { potential } \\
10^{3} \mathrm{~kg} \mathrm{CO}_{2} \text {-eq yr }\end{array}$} \\
\hline & (ha) & (\% of total) & & & & \\
\hline $\begin{array}{l}\text { Intensively managed } \\
\text { grassland }\end{array}$ & 78375 & $68 \%$ & 1653 & 12853 & 313498 & 1134000 \\
\hline $\begin{array}{l}\text { Extensively managed/ } \\
\text { restored grassland }\end{array}$ & 8786 & $8 \%$ & 43 & 1577 & 35145 & 86000 \\
\hline Shallow water bodies & 87 & $6 \%$ & unknown & unknown & $33583^{*}$ & unknown \\
\hline
\end{tabular}

* An annual emission of $0.5 \mathrm{~kg} \mathrm{CO}_{2} \mathrm{~m}^{-2} \mathrm{yr}^{-2}$ was assumed (Table 3).

natural peat vegetation may imply a reduction of the NEE in the future, a less productive system where both uptake and emissions are decreased.

All three sites - Oukoop, Stein and Horstermeer - acted as sources for $\mathrm{CH}_{4}$. Differences in ecosystem $\mathrm{CH}_{4}$ emissions between sites were not significant. However, farm practices in Oukoop and Stein caused an estimated additional emission of 26 and $17 \mathrm{~g} \mathrm{CH}_{4} \mathrm{~m}^{-2}$ directly linked to dairy production. The total $\mathrm{CH}_{4}$ source strength (ecosystem + farm-based emissions) decreases with decreasing management intensity. In the case of the former agricultural site, Horstermeer, the further nature restoration stages will depend on management intensity of the surrounding area affecting groundwater supply and nutrient input and the development of swamp forest depending on, for example, water table management. Nearnatural, less eutrophic temperate grassland systems on peat studied by Van den Pol-van Dasselaar et al. (1999) showed average field- $\mathrm{CH}_{4}$ fluxes of 7.9 and $13.3 \mathrm{~g} \mathrm{~m}^{-2} \mathrm{yr}^{-1}$ and ditch fluxes of 22.5 and $7.3 \mathrm{~g} \mathrm{~m}^{-2} \mathrm{yr}^{-1}$ on average for two more oligotrophic sites, and 20.4 and $4.2 \mathrm{~g} \mathrm{~m}^{-2} \mathrm{yr}^{-1}$ for field and ditch fluxes for a site receiving biannual manure in- puts. After weighing the contributions of water and land $\mathrm{CH}_{4}$ emissions, these values for the two oligotrophic sites are on average considerably lower, and for the more mesotrophic site similar, to emissions measured in Horstermeer. Thus further changes in of $\mathrm{CH}_{4}$ emissions may depend on management of site nutrient balances.

Summer $\mathrm{CH}_{4}$ emissions from lakes appear significantly higher compared to terrestrial emissions from the managed ecosystems but smaller than the emissions from drainage ditches within the managed and restored ecosystems (Schrier-Uijl et al., 2011) and Fig. 9. Comparison of "polder-ecosystem emissions" to emissions from large shallow fresh water lakes implies that water bodies are important contributors to the $\mathrm{CH}_{4}$ balance of Dutch peatlands. Total $\mathrm{CH}_{4}$ polder balances in our study were based on the current classification of the landscape elements, with $16 \%$ open water in Oukoop and Stein and $5 \%$ in Horstermeer. Changing landscape elements, for instance for flood water storage, may cause large changes in the GHG balance. In the establishment of emission factors for the peatlands, these water bodies should be included in further inventories (Schrier-Uijl et 

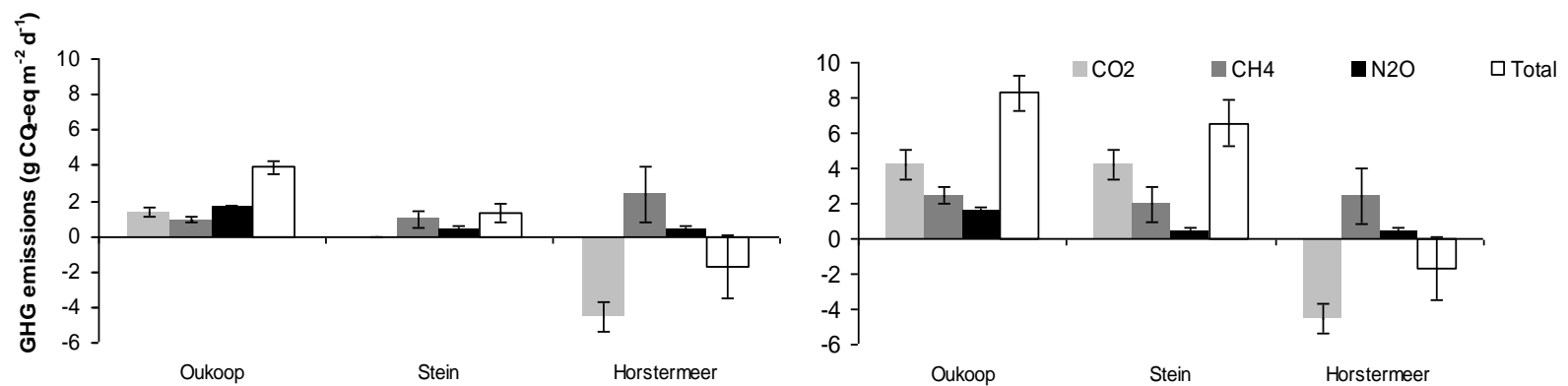

Figure 8. The GHG balances including $\mathrm{CO}_{2}, \mathrm{CH}_{4}$ and $\mathrm{N}_{2} \mathrm{O}$ for the three sites: intensive (Oukoop), extensive (Stein) and restored (Horstermeer). The figure on the left represents ecosystem emissions, excluding farm-based $\mathrm{CH}_{4}$ and $\mathrm{CO}_{2}$ emissions, and on the right including farm-based $\mathrm{CH}_{4}$ and $\mathrm{CO}_{2}$ emissions, averaged over 2006, 2007 and 2008 (fluxes are given in warming potentials, $\mathrm{g} \mathrm{CO}_{2}$-eq m${ }^{-2} \mathrm{~d}^{-1}$ ). All fluxes are given in $\mathrm{g} \mathrm{CO}_{2}$-eq m${ }^{-2} \mathrm{~d}^{-} 1$. The error bars for $\mathrm{CO}_{2}, \mathrm{CH}_{4}$ and $\mathrm{N}_{2} \mathrm{O}$ represent the standard deviation of the mean for 3 years of measurements based on daily values.

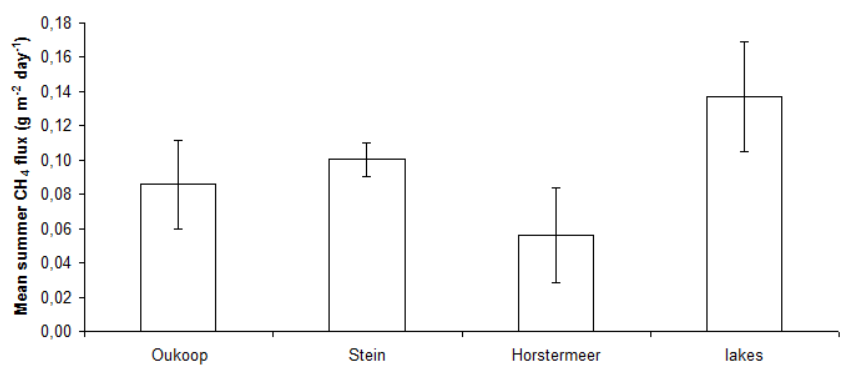

Figure 9. Comparison of summer (June/July) $\mathrm{CH}_{4}$ fluxes between different ecosystems in peatlands. Fluxes are averaged over 3 years for the polder Oukoop (intensive), the polder Stein (extensive) and the polder Horstermeer (restored). The lake fluxes are measured in one summer (June/July, $n=97$ ) season and are averaged over five large shallow lakes; error bars represent the standard deviation of the mean.

al., 2009, 2010; Kankaala et al., 2007; Billet et al., 2012). Reduction of inputs of organic material and nutrients from the surroundings will likely reduce emissions from water bodies (Schrier-Uijl et al., 2009, 2010).

The total $\mathrm{C}$ balance considered in this study included $\mathrm{CO}_{2}-\mathrm{C}, \mathrm{CH}_{4}-\mathrm{C}$, biomass removal, and manure and fertilizer application. The two managed sites acted as $\mathrm{C}$ sources and the restored site acted as a $\mathrm{C}$ sink. In the two managed sites, the $\mathrm{CO}_{2}$ emission (farm-based + terrestrial) and the biomass removal accounted for the largest part of the $\mathrm{C}$ release. Because $\mathrm{C}$ was added through manure and fertilizer inputs in Oukoop, the total $\mathrm{C}$ release turned out to be smaller compared to Stein. In the restored site Horstermeer, the $\mathrm{C}$ balance was dominated by the uptake of $\mathrm{CO}_{2}-\mathrm{C}$. Except for the small release of $\mathrm{C}$ through $\mathrm{CH}_{4}$, no other $\mathrm{C}$ sources or sinks were involved in this undisturbed system. Release of C through ditch water was not significant (Hendriks et al., 2007). Measurements at the three contrasting sites show that an intensively managed fen meadow area can shift from a $\mathrm{C}$ source towards a $\mathrm{C}$ sink when the water table is raised and when land management is reduced to zero. It has to be noted that possible $\mathrm{CO}_{2}$ and/or $\mathrm{CH}_{4}$ spikes after rewetting are not included in the calculations. Upon restoration the ecosystem sink can temporarily be significantly larger (Soini et al, 2010; Wilson et al., 2013). The time needed for stabilization may vary from years to several decades (Tuittila et al, 1999; Samaritani et al., 2011) depending on restoration methods, pre-rewetting circumstances and climate conditions. More research is needed to obtain robust emission factors for this emission after rewetting.

$\mathrm{N}_{2} \mathrm{O}$ emissions are mostly of importance in intensively managed systems. The higher background emission in Oukoop compared to Stein may be attributed to the buildup of easily decomposable organic materials in the soil due to manure application 5 times a year. In Stein this application stopped almost 20 years ago. $\mathrm{N}_{2} \mathrm{O}$ in these types of ecosystems is produced during nitrification and/or denitrification of $\mathrm{NO}^{3-}$. Nitrate is released during mineralization of soil organic $\mathrm{N}$. In peatlands where no manure or fertilizer is applied, $\mathrm{N}$ leaching to ditches is considered negligible according to the IPCC (2006), but this was not measured. Eddy covariance measurements in Oukoop showed a typical pattern of long periods with low emissions (background emissions) followed by short periods of high emissions (peak emissions) around manure application (Kroon et al., 2010b). Peak emissions after manure application accounted for $25 \%$ of the total annual $\mathrm{N}_{2} \mathrm{O}$ emissions in Oukoop. Hensen et al. (2006) show that manure-based emissions from storages around the farm can cause an additional emission of $14.8 \mathrm{mg} \mathrm{N}_{2} \mathrm{O} \mathrm{m}^{3}$ manure $\mathrm{d}^{-1}$. With the $700 \mathrm{~m}^{-3}$ slurry stored around the Oukoop farm this would result in an extra emission of $3.8 \mathrm{~kg} \mathrm{~N}_{2} \mathrm{O} \mathrm{yr}^{-1}$ over 50 ha or $0.08 \mathrm{~kg} \mathrm{~N}_{2} \mathrm{O} \mathrm{ha}^{-1} \mathrm{yr}^{-1}$.

Combining all incoming and outgoing GHG fluxes shows that Oukoop is the largest GHG source in terms of warming potential. $\mathrm{N}_{2} \mathrm{O}$ dominated the emissions in Oukoop and $\mathrm{CO}_{2}$, and $\mathrm{CH}_{4}$ contributed equally. In Stein $\mathrm{N}_{2} \mathrm{O}$ was the least contributing GHG and the total emission was lower compared to Oukoop. The Horstermeer appeared to be a GHG sink with a 
Table 9. Overview of the expected effects of different mitigation strategies on the total GHG balance (ecosystem + farm-based emissions). The effect on the GHG balance has been determined for the three research sites - Oukoop (intensively managed), Stein (extensively managed) and Horstermeer (restored) - and do not include the expected future temperature rise. $(-)$ : decrease in emission; $(+)$ : increase in emission; (0): neutral effect; (?): effect unknown; (x): not relevant.

\begin{tabular}{|c|c|c|c|c|c|c|c|c|c|}
\hline & \multicolumn{3}{|c|}{$\begin{array}{c}\text { Rewetting }+ \text { reduced } \\
\text { management }\end{array}$} & \multicolumn{3}{|c|}{$\begin{array}{l}\text { Management reduced (from } \\
\text { intensively to extensively) }\end{array}$} & \multicolumn{3}{|c|}{$\begin{array}{l}\text { Increase in } \% \\
\text { open water }\end{array}$} \\
\hline & $\mathrm{CO}_{2}$ & $\mathrm{CH}_{4}$ & $\mathrm{~N}_{2} \mathrm{O}$ & $\mathrm{CO}_{2}$ & $\mathrm{CH}_{4}$ & $\mathrm{~N}_{2} \mathrm{O}$ & $\mathrm{CO}_{2}$ & $\mathrm{CH}_{4}$ & $\mathrm{~N}_{2} \mathrm{O}$ \\
\hline Intensive management & - & - & - & 0 & - & - & - & + & - \\
\hline Extensive management & - & - & - & $\mathrm{x}$ & $\mathrm{x}$ & $\mathrm{x}$ & - & + & $?$ \\
\hline Restoration & $\mathrm{x}$ & $\mathrm{x}$ & $\mathrm{x}$ & $\mathrm{x}$ & $\mathrm{x}$ & $\mathrm{x}$ & - & + & $?$ \\
\hline Open water* & - & - & - & - & - & - & $\mathrm{x}$ & $\mathrm{x}$ & $\mathrm{x}$ \\
\hline
\end{tabular}

* The influence of rewetting and land management reduction in the surrounding area on emissions from "open water".

release of $\mathrm{CH}_{4}$ and $\mathrm{N}_{2} \mathrm{O}$ from the system but a large uptake of $\mathrm{CO}_{2}$. This suggests that changing the management from intensive to extensive and further to restored may change the total GHG balance from release to uptake. Water bodies were large contributors to the GHG balance when considering summer emissions of $\mathrm{CO}_{2}$ and $\mathrm{CH}_{4}$ (Schrier-Uijl et al., 2009, 2010).

\subsection{Potential ways for mitigation}

Mitigation of $\mathrm{CO}_{2}, \mathrm{CH}_{4}$ and $\mathrm{N}_{2} \mathrm{O}$ in peatland areas is important for two reasons: (1) to maintain this ecosystem and stop the degradation of peat soils and soil subsidence and (2) to reduce GHG emissions from drained peatlands. Strategies to reduce GHG emissions from these areas and to increase C uptake may be oriented toward rewetting of intensively cultivated peatlands combined with reducing farm-based fluxes and decreasing management intensity.

This study shows that rewetting of agricultural peatland may turn areas of $\mathrm{C}$ release into areas of C uptake; the GHG balance switched from GHG source to sink. The effect might be even stronger in peat soils that lack a clay layer on top of the peat since these peat soils are extremely vulnerable to oxidation (Schothorst, 1977) and subsidence. The dynamic water tables in the extensively managed polder (high water tables in winter and low water tables in summer) resulted in only a small reduction in GHG emission mainly due to a decrease in farm-based $\mathrm{CH}_{4}$ emissions and a reduction in $\mathrm{N}_{2} \mathrm{O}$ emissions because no fertilizer is applied. High water tables both in winter and in summer will likely reduce emissions. The long-term duration for the sink strength in the restored polder may slow down at centennial timescales due to a decrease in nutrient availability and thus decreased growth of vegetation (Wilson et al., 2013).

Farm-based emissions may be alterable. Sommer et al. (2009) studied farm-based emissions in Sweden, Denmark, France and Italy. The results showed that shortening the in-house manure storage and decreasing storage temperatures reduced GHG emissions from manure by $0-40 \%$ depending on current management and climatic conditions. Large GHG reductions were obtained with slurry separation in a liquid phase and a solid, organic phase in combination with the early application of the liquid fraction compared to the solid fraction.

\section{Conclusions}

The aim of this study was to test whether the GHG and C balance changes if agricultural peatlands are restored and rewetted. Three sites with comparable characteristics, in the same peat area in the Netherlands, have been studied, and results of long-term measurements have been analysed, combined with the data sets that were already available from other studies in the same sites, and compared. Because of their importance, water bodies are included in the analyses. The merging and extension of existing data sets enabled determination of the influence of rewetting/restoration on the GHG balance of agricultural sites. The results of this study strongly suggest that rewetting of agricultural peatland and reduction of management intensity may turn areas of $\mathrm{C}$ release into area of C uptake; the GHG balance switched from GHG source to sink. The switch from an intensively managed peatland to an extensively managed peatland did not significantly alter the ecosystem GHG balance; however, the total (ecosystem + farm-based) emissions decreased significantly if farmbased emissions were zero in the extensively managed site. Conclusions related to the effect of management on GHG emissions from peatlands are summarized in Table 9.

\section{The Supplement related to this article is available online at doi:10.5194/bg-11-4559-2014-supplement.}


Acknowledgements. This study was funded by Wageningen University, The Province of North Holland, CarboEurope IP (contract number: GOCE-CT-2003-505572) and the Climate for Spatial Planning Project. Many thanks to our partners in this project who contributed to this study, as well as the farmers and the State Forestry Service that provided logistical support and access to their fields. We thank our referees for the comments on the earlier versions of this paper.

Edited by: P. Stoy

\section{References}

Aubinet, M., Grelle, A., Ibrom, A., Rannik, U., Moncrieff, J., Foken, T., Kowalski, A. S., Martin, P. H., Berbigier, P., Bernhofer, C., Clement, R., Elbers, J., Granier, A., Grunwald, T., Morgenstern, K., Pilegaard, K., Rebmann, C., Snijders, W., Valentini, R., and Vesala T.: Estimates for the annual net carbon and water exchange of forests, The EUROFLUX methodology, Adv. Ecol. Res., 30, 113-175, 2000.

Baldocchi, D., Falge, E., Gu, L. H., Olson, R., Hollinger, D., Running, S., Anthoni, P., Bernhofer, C., Davis, K., Evans, R., Fuentes, J., Goldstein, A., Katul, G., Law, B., Lee, X. H., Malhi, Y., Meyers, T., Munger, W., Oechel, W., U, K. T. P., Pilegaard, K., Schmid, H. P., Valentini, R., Verma, S., Vesala, T., Wilson, K., and Wofsy, S.: Fluxnet, A new tool to study the temporal and spatial variability of ecosystem scale- carbon dioxide and energy flux densities, B. Am. Meteorol. Soc., 82, 2415-2434, 2001.

Billet, M. F. and Harvey, F. H.: Measurements of $\mathrm{CO}_{2}$ and $\mathrm{CH}_{4}$ evasion from UK peatland headwater streams, Biogeochemistry, 114, 165-181, doi:10.1007/S10533-012-9798-9, 2012.

Carter, M. S., Larsen, K. S., Emmett, B., Estiarte, M., Field, C., Leith, I. D., Lund, M., Meijide, A., Mills, R. T. E., Niinemets, Ü., Peñuelas, J., Portillo-Estrada, M., Schmidt, I. K., Selsted, M. B., Sheppard, L. J., Sowerby, A., Tietema, A., and Beier, C.: Synthesizing greenhouse gas fluxes across nine European peatlands and shrublands - responses to climatic and environmental changes, Biogeosciences, 9, 3739-3755, doi:10.5194/bg-93739-2012, 2012.

Foken, Th. and Wichura, B.: Tools for quality assessment of surface-based flux measurements, Agr. Forest Meteorol., 78, 83105, 1996.

Gash, J. H. C. and Dolman, A. J.: Sonic anemometer (co)sine response and flux measurement I. The potential for (co)sine error to affect sonic anemometer-based flux measurements, Agr. Forest Meteorol., 119, 195-207, 2003.

Gorham, E., Lehman, C., Dyke, A., Clymo, D., and Janssens, J: Long-term carbon sequestration in North American peatlands, Quaternary Sci. Rev., 58, 77-82, 2012.

Hendriks, D. M. D.: thesis: Integrated observations of greenhouse gas budgets at the ecosystem level - changing environment and management practices in peat meadows, 2009.

Hendriks, D. M. D., van Huissteden, J., Dolman, A. J., and van der Molen, M. K.: The full greenhouse gas balance of an abandoned peat meadow, Biogeosciences, 4, 411-424, doi:10.5194/bg-4411-2007, 2007.

Hendriks, D. M. D., van Huissteden, J., and Dolman, A. J.: Multitechnique assessment of spatial and temporal variability of methane fluxes in a peat meadow, Agr. Forest Meteorol., 150, 757-774, doi:10.1016/j.agrformet.2009.06.017, 2009.

Hensen, A., Groot, T. T., and van den Bulk, W. C. M: Dairy farm emissions, from one square meter to the full farm scale, Agr. Ecosyst. Environ., 112, 146-152, 2006.

IPCC 2006: Guidelines for National Greenhouse Gas Inventories, Prepared by the National Greenhouse Gas Inventories Programme, edited by: Eggleston, H. S., Buendia, L., Miwa, K., Ngara T., and Tanabe, K., IGES, Japan, 2006.

IPCC 2007: The Physical Science Basis, Contribution of Working Group I to the Fourth Assessment Report of the Intergovernmental Panel on Climate Change, Cambridge University Press, Cambridge, United Kingdom and New York, NY, USA, 2007.

Joosten, H. and Clarke, D.: Wise use of mires and peatlands Background and principles including a framework for decisionmaking, International Mire Conservation Group/International Peat Society, 304 pp., 2002.

Kankaala, P., Taipale, S., Nykänen, H., and Jones, R. I.: Oxidation, efflux, and isotopic fractionation of methane during autumnal turnover in a polyhumic, boreal lake, J. Geophys. Res.-Biogeo., 112, G02033, doi:10.1029/2006JG000336, 2007.

Kempen, B., Brus, D. J., Heuvelink, G. B. M., and Stoorvogel, J. J.: Updating the 1:50,000 Dutch soil map using legacy soil data: A multinomial logistic regression approach, Geoderma, 151, 311326, 2009.

Kormann, R. and Meixner, F. X.: An analytical footprint model for neutral stratification, Bound.-Lay. Meteor., 99, 207-224, 2001.

Kroon, P. S., Hensen, A., Jonker, H. J. J., Zahniser, M. S., van 't Veen, W. H., and Vermeulen, A. T.: Suitability of quantum cascade laser spectroscopy for $\mathrm{CH}_{4}$ and $\mathrm{N}_{2} \mathrm{O}$ eddy covariance flux measurements, Biogeosciences, 4, 715-728, doi:10.5194/bg-4715-2007, 2007.

Kroon, P. S., Hensen, A., van den Bulk, W. C. M., Jongejan, P. A. C., and Vermeulen, A. T.: The importance of reducing the systematic error due to non-linearity in $\mathrm{N}_{2} \mathrm{O}$ flux measurements by static chambers, Nutr. Cycl. Agroecosyst., 82, 175-186, 2008.

Kroon, P. S., Hensen, A., Jonker, H. J. J., Ouwersloot, H. G., Vermeulen, A. T., and Bosveld, F. C.: Uncertainties in eddy covariance flux measurements assessed from $\mathrm{CH}_{4}$ and $\mathrm{N}_{2} \mathrm{O}$ observations, Agr. Forest Meteorol., 150, 806-816, doi:10.1016/j.agrformet.2009.08.008, 2010a.

Kroon, P. S., Schrier-Uijl, A. P., Hensen, A., Veenendaal, E. M., and Jonker, H. J. J.: Annual balances of $\mathrm{CH}_{4}$ and $\mathrm{N}_{2} \mathrm{O}$ from a managed fen meadow using eddy covariance flux measurements, Eur. J. Soil Sci., 61, 773-784, doi:10.1111/j.13652389.2010.01273.x, 2010b.

Kroon, P. S: Thesis: Eddy covariance observations of methane and nitrous oxide emissions - towards more accurate estimates from ecosystems. Technische Universiteit Delft, ISBN: 978-909025388-6, 2010c.

Langeveld, C. A., Segers, R., Dirks, B. O. M., Van den Pol-van Dasselaar, A., Velthof, G. C., and Hensen, A.: Emissions of $\mathrm{CO}_{2}$, $\mathrm{CH}_{4}$ and $\mathrm{N}_{2} \mathrm{O}$ from pasture on drained peat soils in the Netherlands, Eur. J. Agron., 7, 25-42, 1997.

Lloyd, J. and Taylor, J. A.: On the temperature dependency of soils, Funct. Ecol., 8, 315-323, 1994.

Lloyd, C. R.: Annual carbon balance of a managed wetland meadow in the Somerset Levels, UK, Agr. Forest Meteorol., 138, 168179, 2006. 
Miranda, A. C., Miranda, H. S., and Lloyd, J.: Fluxes of carbon, water and energy over Brazilian cerrado: an analysis using eddy covariance and stable isotopes, Plant Cell Environ., 20, 315-332, 1997.

Nakai, T., Van der Molen, M. K., Gash, J. H. C., and Kodama, Y.: Correction of sonic anemometer angle of attack errors, Agr. Forest Meteorol., 136, 19-30, doi:10.1016/j.agrformet.2006.01.006, 2006.

Nieveen, J. P., Campbell, D. I., Schipper, L. A., and Blair, I. J.: C exchange of grazed pasture on a drained peat soil, Glob. Change Biol., 11, 607-618, 2005.

Nol, L., Verburg, P. H., Heuvelink, G. B. M., and Molenaar, K.: Effect of land cover data on nitrous oxide inventory in fen meadows, J. Environ. Quality, 37, 1209-1219, 2008.

Raamsdonk, L. W. D., Kan, C. A., Meijer, G. A. L., and Kemme, P. A.: Kengetallen van enkele landbouwhuisdieren en hun consumptiepatronen, Rapport 2007.010, RIKILT - Instituut voor voedselveiligheid, 2007 (in Dutch).

Samaritani, E., Siegenthaler, A., Yli-Petäys, M., Buttler, A., Christin, P.-A., and Mitchell, E. A. D. Seasonal net ecosystem carbon exchange of a regenerating cutaway bog: How long does it take to restore the $\mathrm{C}$ sequestration function, Restoration Ecol., 19, 480-489, 2011.

Schrier-Uijl, A. P., Kroon, P. S., Hensen, A., Leffelaar, P. A., Berendse, F., and Veenendaal, E. M.: Comparison of chamber and eddy covariance based $\mathrm{CO}_{2}$ and $\mathrm{CH}_{4}$ emission estimates in a heterogeneous grass ecosystem on peat, Agr. Forest Meteorol., 150, 825-831, doi:10.1016/j.agrformet.2009.11.007, 2009.

Schrier-Uijl, A. P., Veenendaal, E. M., Leffelaar, P. A., van Huissteden, J. C., and Berendse, F.: Methane emissions in two drained peat agro-ecosystems with high and low agricultural intensity, Plant Soil, 329, 509-520, doi:10.1007/s11104-009-01801, 2010.

Schrier-Uijl, A. P., Veraart, A.J., Leffelaar, P. A., Berendse, F., and Veenendaal, E. M: Release of $\mathrm{CO}_{2}$ and $\mathrm{CH}_{4}$ from lakes and drainage ditches in temperate wetlands, Biogeochemistry, 102, 265-279, doi:10.1007/s10533-010-9440-7, 2011.

Schuepp, P. H., Leclerc, M. Y., McPherson, J. I., and Desjardins, R. L.: Footprint prediction of scalar fluxes from analytical solutions of the diffusion equation, Bound.-Layer Meteor., 50, 355-374, 1990.

Sneath, W., Beline, F., Hilhorst, A., and Peu, P.: Monitoring GHG from manure stores on organic and conventional dairy farms, Agr. Ecosyst. Environ., 112, 122-128, 2006.

Soini, P., Riutta, T., Yli-Petäys, M., and Vasander, H.: Comparison of vegetation and $\mathrm{CO}_{2}$ dynamics between a restored cut-way peatland and a pristine fen: evaluation of the restoration success, Restoration Ecol., 18, 894-903, 2010.
Sommer, S. G., Olesen, J. E., Petersen, S. O., Weisberg, M. R., Vallis, L., Rodhe, L., and Beline, F.: Region-specific assessment of greenhouse gas mitigation with different manure management strategies in four agro ecological zones, Glob. Change Biol., 15, 2825-2837, 2009.

TDN: TOP10vector Product information: Topografische Dienst Kadaster Emmen the Netherlands, available at: http://www.tdn. nl/ (last access: 6 December 2007), 2006 (in Dutch).

Teh, Y. A., Silver, W. L., Sonnentag, O., Detto, M., Kelly, M., and Baldocchi, D. D.: Large Greenhouse Gas Emissions from a Temperate Peatland Pasture, Ecosystems, 14, 311-325, doi:10.1007/s10021-011-9411-4, 2011.

Tuittila, E.-S., Komulainen, V.-M., Vasander, H., and Laine, J.: Restored cut-away peatland as a sink for atmospheric $\mathrm{CO}_{2}$, Oecologia, 120, 563-574, 1999.

Van Amstel, A., Kroeze, C., van Eerdt, M., Dumont, M., and Both, D.: National emissions of methane and nitrous oxide from agriculture in The Netherlands: current estimates and future trends, Workshop on Inventories and projections of greenhouse gas and ammonia emissions from agriculture, 27-28 February 2003, European Environmental Agency, Copenhagen, 2003.

Van Buren, J., Westerik, A., and Olink, E. J. H.: Quality Top10Vector. The geometric quality of the database top10Vector of the Dutch National Mapping Agency, Topografische Dienst Kadaster, Emmen, The Netherlands, 2003 (in Dutch).

Van der Molen, M. K., Gash, J. H. C., and Elbers, J. A.: Sonic anemometer (co)sine response and flux measurement - II. The effect of introducing an angle of attack dependent calibration, Agr. Forest Meteorol., 122, 95-109, 2004.

Van den Pol-van Dasselaar, A., Van Beusichem, M. L., Oenema, O.: Effects of nitrogen input and grazing on methane fluxes of extensively and intensively managed grasslands in the Netherlands, Biol. Fertil. Soils, 29, 24-30, 1999.

Veenendaal, E. M., Kolle, O., Leffelaar, P. A., Schrier-Uijl, A. P., Van Huissteden, J., Van Walsem, J., Möller, F., and Berendse, F.: $\mathrm{CO}_{2}$ exchange and carbon balance in two grassland sites on eutrophic drained peat soils, Biogeosciences, 4, 1027-1040, doi:10.5194/bg-4-1027-2007, 2007.

Velthof, G. L. and Oenema, O.: Nitrous oxide emission from dairy farming systems in the Netherlands, Netherlands J. Agr. Sci., 45, 347-360, 1997.

Webb, E. K., Spearman, G. I., and Leuning, R.: Correction of flux measurements for density effects due to heat and water vapour transfer, Q. J. Roy. Meteor. Soc., 106, 85-100, 1980.

Wilson, D., Farrell, C., Mueller, C., Hepp, S., and Renou-Wilson, F.: Rewetted industrial cutaway peatlands in western Ireland: a prime location for climate change mitigation?, Mires Peat, 11, $1-22,2013$ 